\title{
LEVEL II SCOUR ANALYSIS FOR BRIDGE 21 (MORETH00010021) on TOWN HIGHWAY 1, crossing COX BROOK, MORETOWN, VERMONT
}

Open-File Report 97-662

Prepared in cooperation with

VERMONT AGENCY OF TRANSPORTATION

and

FEDERAL HIGHWAY ADMINISTRATION

U.S. Department of the Interior

U.S. Geological Survey

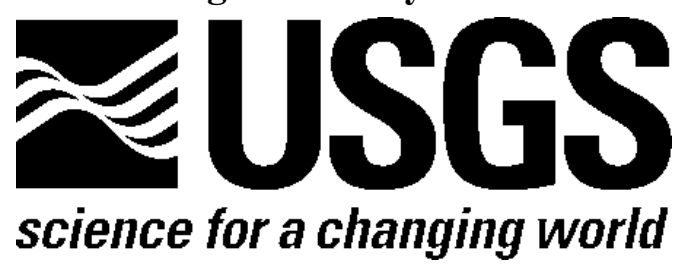




\section{LEVEL II SCOUR ANALYSIS FOR BRIDGE 21 (MORETH00010021) on TOWN HIGHWAY 1, crossing COX BROOK, MORETOWN, VERMONT \\ By LORA K. STRIKER AND LAURA MEDALIE}

U.S. Geological Survey

Open-File Report 97-662

Prepared in cooperation with

VERMONT AGENCY OF TRANSPORTATION

and

FEDERAL HIGHWAY ADMINISTRATION 


\title{
U.S. DEPARTMENT OF THE INTERIOR BRUCE BABBITT, Secretary
}

\author{
U.S. GEOLOGICAL SURVEY \\ Mark Schaefer, Acting Director
}

For additional information write to:

District Chief

U.S. Geological Survey 361 Commerce Way

Pembroke, NH 03275-3718
Copies of this report may be purchased from:

U.S. Geological Survey

Branch of Information Services

Open-File Reports Unit

Box 25286

Denver, CO 80225-0286 


\section{CONTENTS}

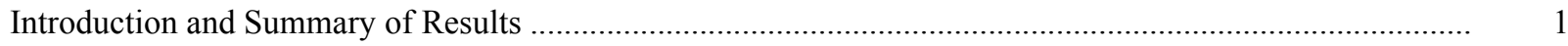

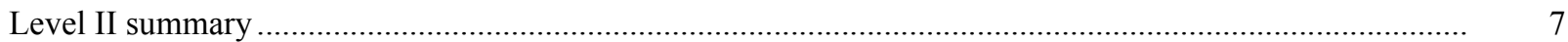

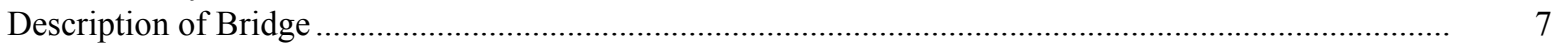

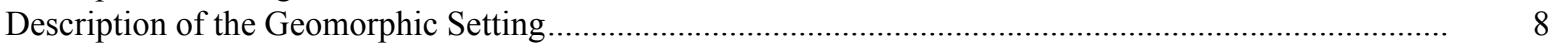

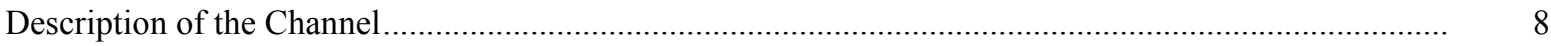

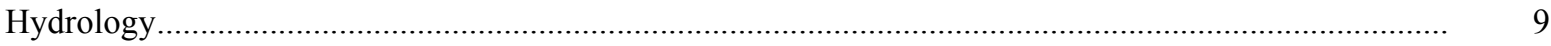

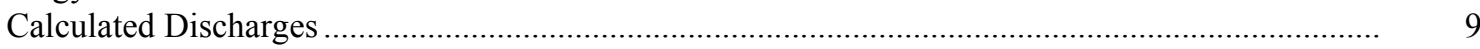

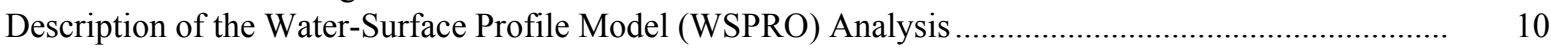

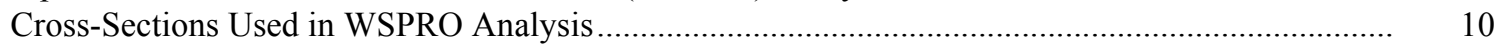

Data and Assumptions Used in WSPRO Model ...................................................................... 11

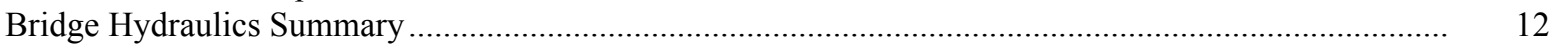

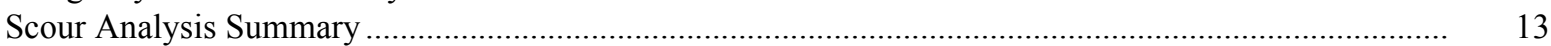

Special Conditions or Assumptions Made in Scour Analysis ...................................................... 13

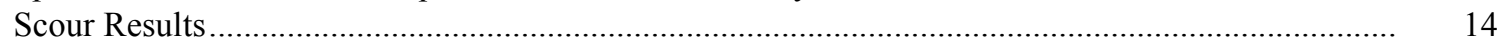

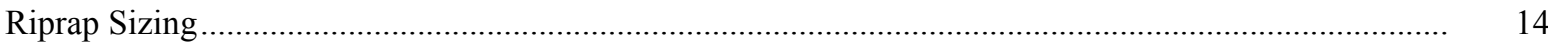

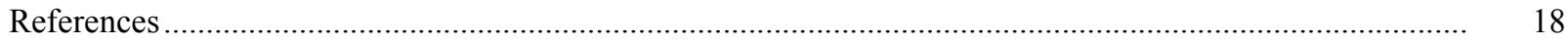

Appendixes:

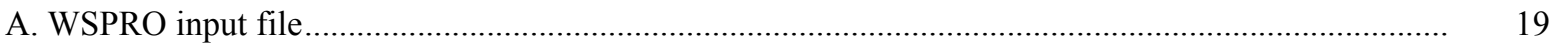

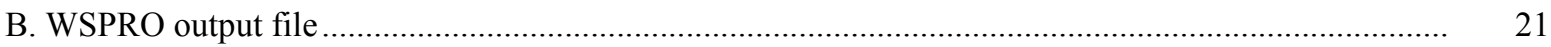

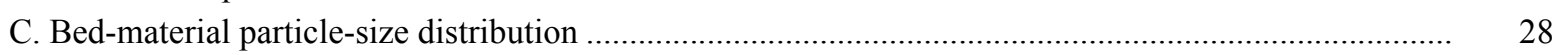

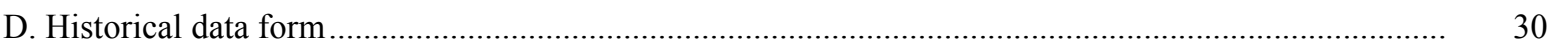

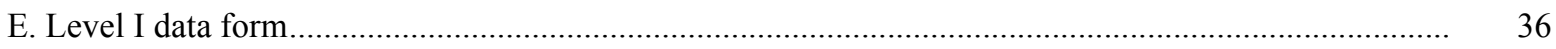

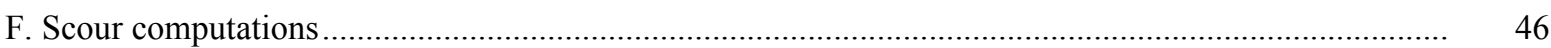

\section{FIGURES}

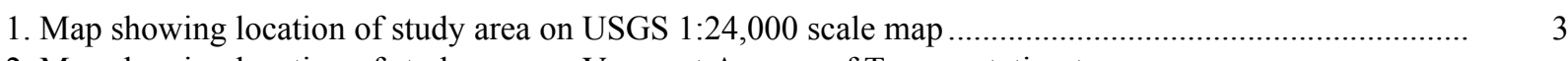

2. Map showing location of study area on Vermont Agency of Transportation town
highway map

3. Structure MORETH00010021 viewed from upstream (July 18, 1996) …...............................................

4. Downstream channel viewed from structure MORETH00010021 (July 18, 1996).............................. 5

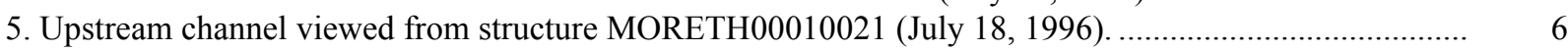

6. Structure MORETH00010021 viewed from downstream (July 18, 1996)......................................... 6

7. Water-surface profiles for the 100- and 500-year discharges at structure

MORETH00010021 on Town Highway 1, crossing Cox Brook,

Moretown, Vermont.

8. Scour elevations for the 100- and 500-year discharges at structure

MORETH00010021 on Town Highway 1, crossing Cox Brook,

Moretown, Vermont.

\section{TABLES}

1. Remaining footing/pile depth at abutments for the 100-year discharge at structure MORETH00010021 on Town Highway 1, crossing Cox Brook,

Moretown, Vermont.

2. Remaining footing/pile depth at abutments for the 500-year discharge at structure

MORETH00010021 on Town Highway 1, crossing Cox Brook,

Moretown, Vermont. 


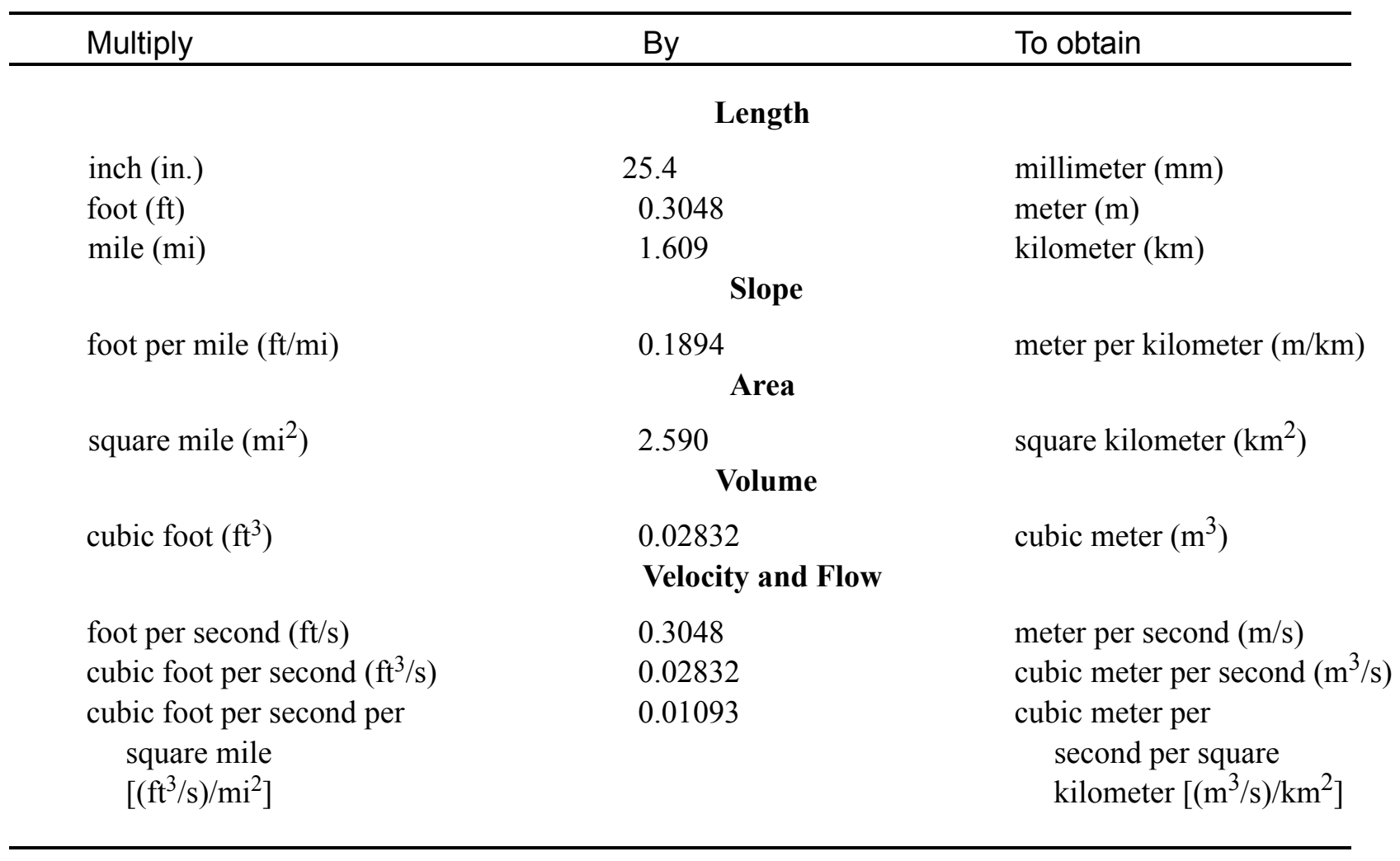

\section{OTHER ABBREVIATIONS}

$\begin{array}{lrlr}\mathrm{BF} & \text { bank full } & \text { LWW } & \text { left wingwall } \\ \mathrm{cfs} & \text { cubic feet per second } & \text { MC } & \text { main channel } \\ \mathrm{D}_{50} & \text { median diameter of bed material } & \text { RAB } & \text { right abutment } \\ \mathrm{DS} & \text { downstream } & \text { RABUT } & \text { face of right abutment } \\ \mathrm{elev} & \text { elevation } & \text { RB } & \text { right bank } \\ \mathrm{f} / \mathrm{p} & \text { flood plain } & \text { ROB } & \text { right overbank } \\ \mathrm{ft}^{2} & \text { square feet } & \text { RWW } & \text { right wingwall } \\ \mathrm{ft} / \mathrm{ft} & \text { feet per foot } & \text { TH } & \text { town highway } \\ \mathrm{JCT} & \text { junction } & \text { UB } & \text { under bridge } \\ \mathrm{LAB} & \text { left abutment } & \text { US } & \text { upstream } \\ \mathrm{LABUT} & \text { face of left abutment } & \text { USGS } & \text { United States Geological Survey } \\ \mathrm{LB} & \text { left bank } & \text { VTAOT Vermont Agency of Transportation } \\ \mathrm{LOB} & \text { left overbank } & \text { WSPRO } & \text { water-surface profile model }\end{array}$

In this report, the words "right" and "left" refer to directions that would be reported by an observer facing downstream. Sea level: In this report, "sea level" refers to the National Geodetic Vertical Datum of 1929-- a geodetic datum derived from a general adjustment of the first-order level nets of the United States and Canada, formerly called Sea Level Datum of 1929.

In the appendices, the above abbreviations may be combined. For example, USLB would represent upstream left bank. 


\title{
LEVEL II SCOUR ANALYSIS FOR BRIDGE 21 (MORETH00010021) ON TOWN HIGHWAY 1, CROSSING COX BROOK, MORETOWN, VERMONT
}

\author{
By Lora K. Striker and Laura Medalie
}

\section{INTRODUCTION AND SUMMARY OF RESULTS}

This report provides the results of a detailed Level II analysis of scour potential at structure MORETH00010021 on Town Highway 1 crossing Cox Brook, Moretown, Vermont (figures 1-8). A Level II study is a basic engineering analysis of the site, including a quantitative analysis of stream stability and scour (U.S. Department of Transportation, 1993). Results of a Level I scour investigation also are included in Appendix E of this report. A Level I investigation provides a qualitative geomorphic characterization of the study site. Information on the bridge, gleaned from Vermont Agency of Transportation (VTAOT) files, was compiled prior to conducting Level I and Level II analyses and is found in Appendix D.

The site is in the Green Mountain section of the New England physiographic province in north-central Vermont. The $2.85-\mathrm{mi}^{2}$ drainage area is in a predominantly rural and forested basin. In the vicinity of the study site, the surface cover is predominantly forested.

In the study area, Cox Brook has an incised, sinuous channel with a slope of approximately $0.02 \mathrm{ft} / \mathrm{ft}$, an average channel top width of $23 \mathrm{ft}$ and an average bank height of $4 \mathrm{ft}$. The channel bed material ranges from gravel to cobble with a median grain size $\left(D_{50}\right)$ of 47.5 $\mathrm{mm}(0.156 \mathrm{ft})$. The geomorphic assessment at the time of the Level I and Level II site visit on July 18, 1996, indicated that the reach was stable.

The Town Highway 1 crossing of Cox Brook is a 29-ft-long, two-lane bridge consisting of one 27-foot steel-beam span (Vermont Agency of Transportation, written communication, October 13, 1995). The opening length of the structure parallel to the bridge face is $24.8 \mathrm{ft}$. The bridge is supported by vertical, concrete abutments with wingwalls. The channel is skewed approximately 60 degrees to the opening while the measured opening-skew-toroadway is 40 degrees.

A scour hole $1.0 \mathrm{ft}$ deeper than the mean thalweg depth was observed along the left abutment downstream during the Level I assessment. The only scour protection measure at the site was type-2 stone fill (less than 36 inches diameter) along the left bank upstream. Additional details describing conditions at the site are included in the Level II Summary and Appendices D and E. 
Scour depths and recommended rock rip-rap sizes were computed using the general guidelines described in Hydraulic Engineering Circular 18 (Richardson and others, 1995) for the 100-year and 500-year discharges. In addition, the incipient roadway-overtopping discharge is determined and analyzed as another potential worst-case scour scenario. Total scour at a highway crossing is comprised of three components: 1) long-term streambed degradation; 2) contraction scour (due to accelerated flow caused by a reduction in flow area at a bridge) and; 3 ) local scour (caused by accelerated flow around piers and abutments). Total scour is the sum of the three components. Equations are available to compute depths for contraction and local scour and a summary of the results of these computations follows.

Contraction scour for all modelled flows ranged from 0.2 to $0.5 \mathrm{ft}$. The worst-case contraction scour occurred at the incipient roadway-overtopping discharge, which was less than the 100-year discharge. Abutment scour ranged from 2.8 to $4.0 \mathrm{ft}$. The worst-case abutment scour occurred at the left abutment at the 100-year discharge and at the right abutment at the 500-year discharge. Additional information on scour depths and depths to armoring are included in the section titled "Scour Results". Scoured-streambed elevations, based on the calculated scour depths, are presented in tables 1 and 2. A cross-section of the scour computed at the bridge is presented in figure 8. Scour depths were calculated assuming an infinite depth of erosive material and a homogeneous particle-size distribution.

It is generally accepted that the Froehlich equation (abutment scour) gives "excessively conservative estimates of scour depths" (Richardson and others, 1995, p. 47). Usually, computed scour depths are evaluated in combination with other information including (but not limited to) historical performance during flood events, the geomorphic stability assessment, existing scour protection measures, and the results of the hydraulic analyses. Therefore, scour depths adopted by VTAOT may differ from the computed values documented herein. 


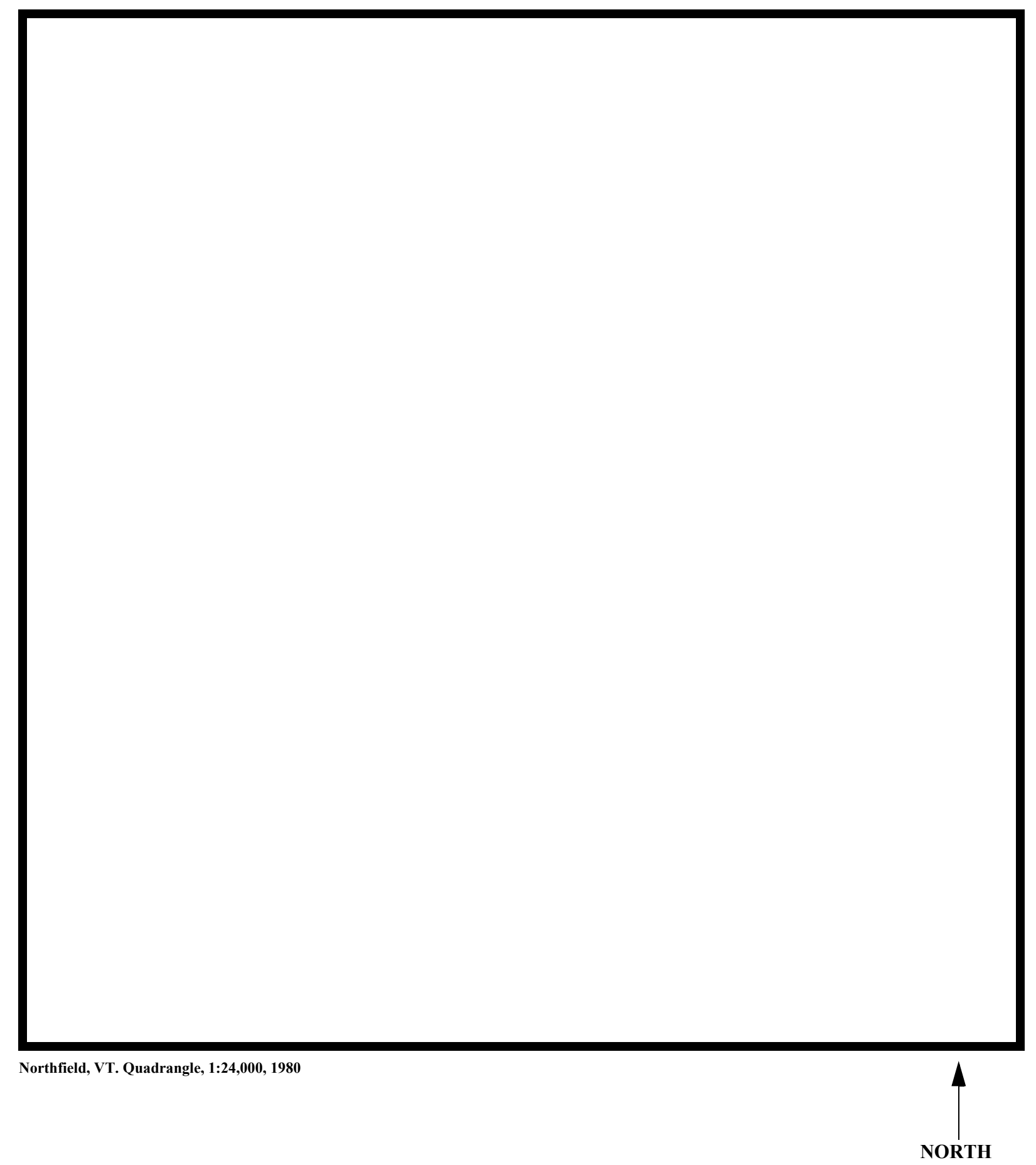

Figure 1. Location of study area on USGS 1:24,000 scale map. 
Figure 2. Location of study area on Vermont Agency of Transportation town highway map. 

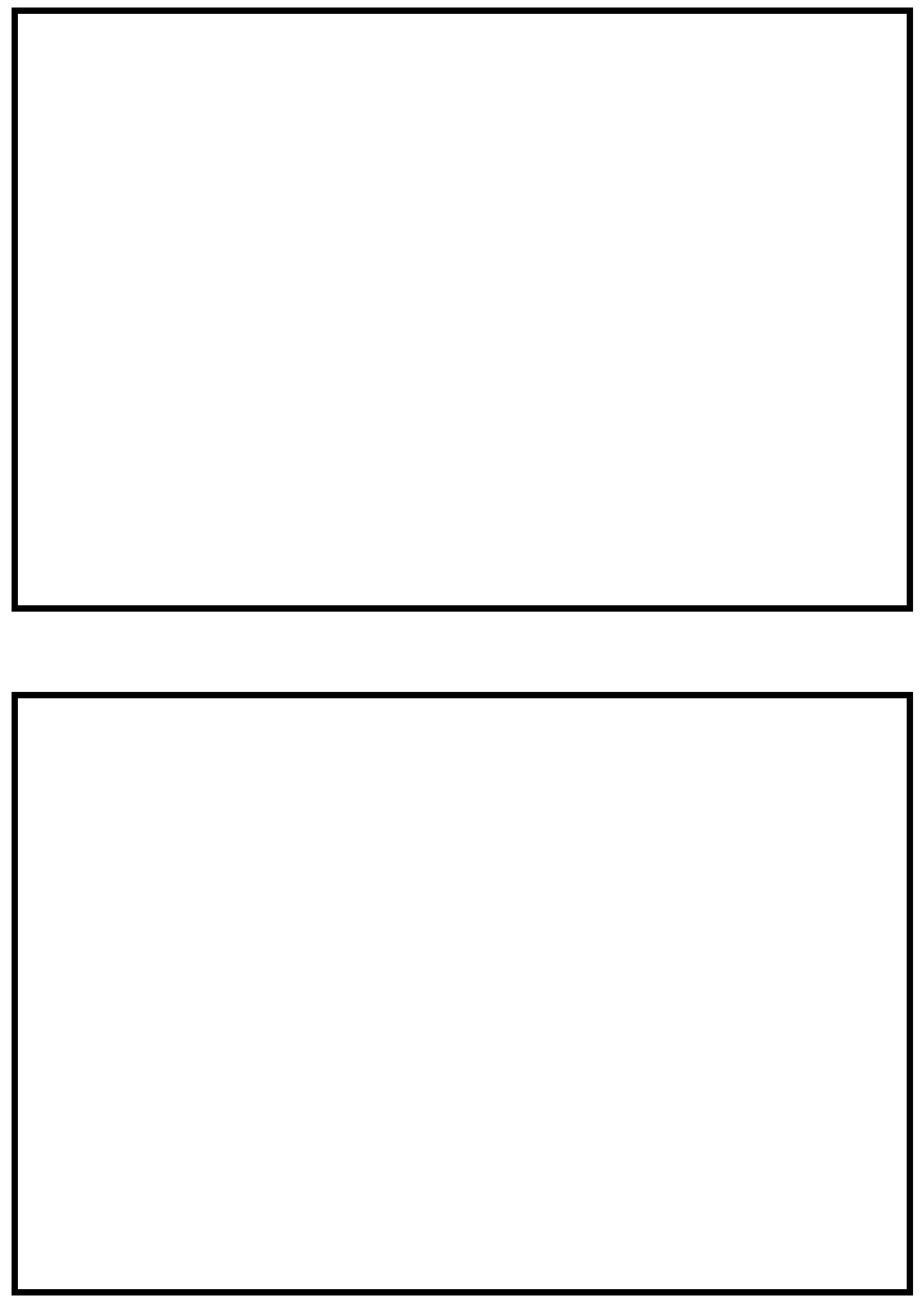

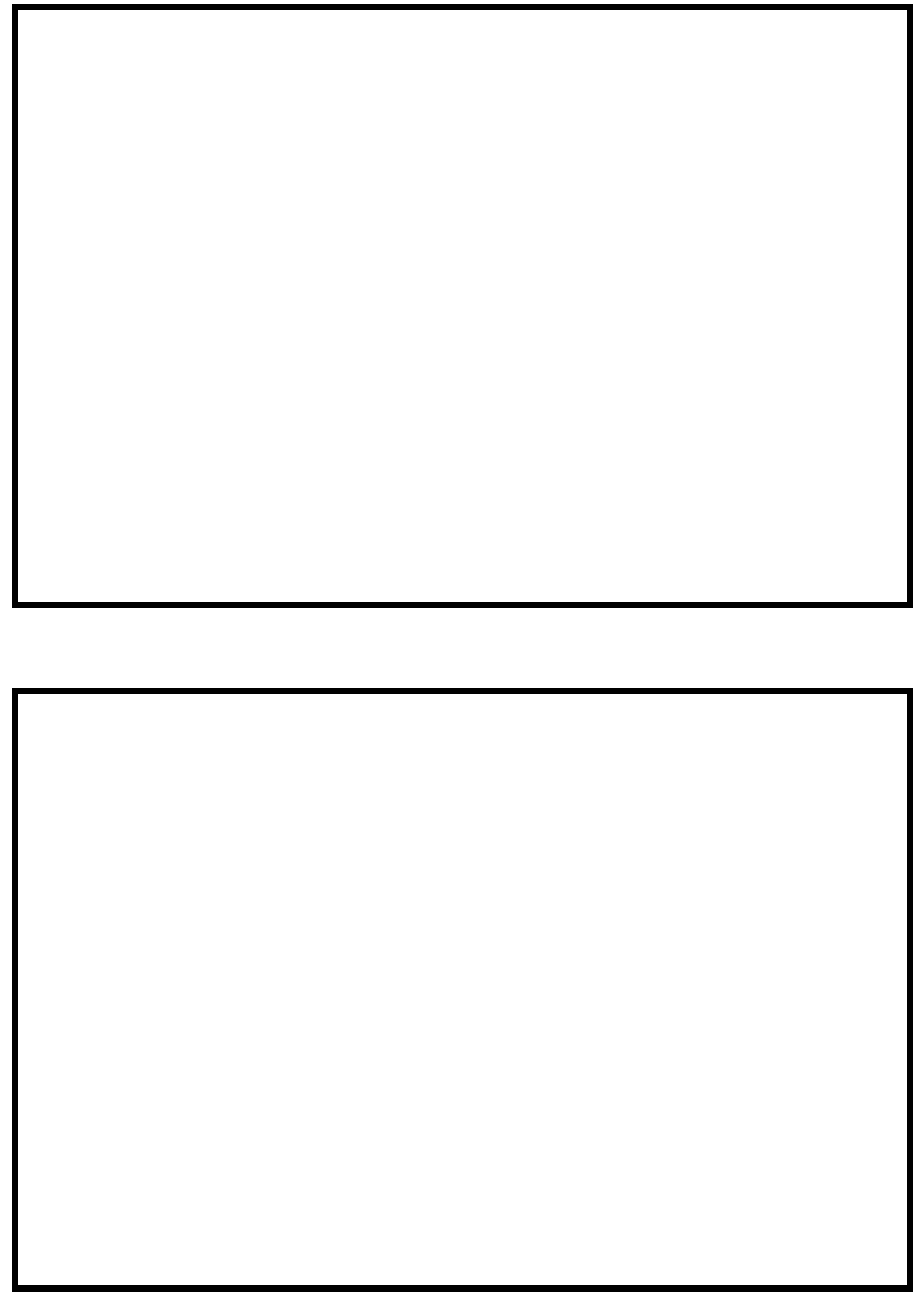


\section{LEVEL II SUMMARY}

\begin{tabular}{lllllll} 
Structure Number & \multicolumn{2}{c}{ MORETH00010021 } & Stream & \multicolumn{2}{c}{ Cox Brook } & \\
& & & & & \\
County & Washington & Road & TH 1 & District & 6
\end{tabular}

\section{Description of Bridge}

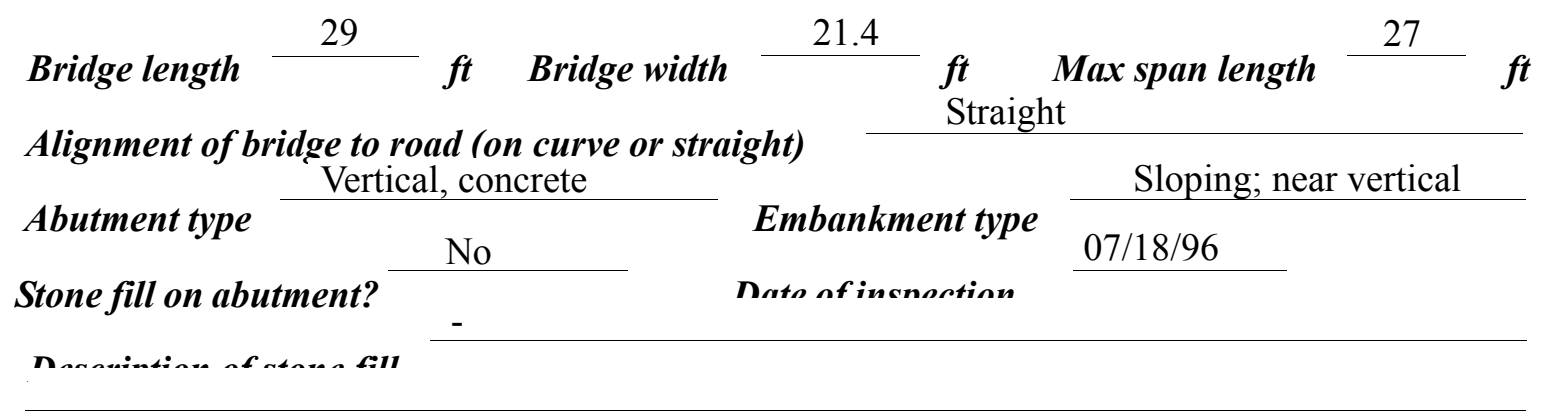

Abutments and wingwalls are concrete. There are random cracks with displacement at the wingwalls. The abutment concrete has cracks and spalls. The left abutment footing is exposed.

$\mathrm{Y}$

Is bridge skewed to flood flow according to Y ' survey? Angle

There is a mild channel bend in the upstream reach.

Debris accumulation on bridge at time of Level I or Level II site visit:

\begin{tabular}{|c|c|c|c|}
\hline & $\begin{array}{c}\text { Date of incnortion } \\
07 / 18 / 96 \\
\end{array}$ & $\begin{array}{l}\text { Percent of nhamual } \\
\text { bloeked inortzontatly }\end{array}$ & $\begin{array}{l}\text { Percent of } 0 \\
\text { blocked vertteatty }\end{array}$ \\
\hline & $07 / 18 / 96$ & 0 & 0 \\
\hline
\end{tabular}

Level II

Moderate. The low vertical clearance contributes to the capture efficiency of the bridge.

Potential for debris

Dosrriho any, fonturos noar ar at tho hridoo that mav, affort flow, (includo ahsorvation dato) 


\section{Description of the Geomorphic Setting}

General topography The channel is located within a moderate relief valley, with moderately

sloping overbanks.

Geomorphic conditions at bridge site: downstream (DS), upstream (US)

Date of inspection $\quad 07 / 18 / 96$

DS left: $\quad$ Steep channel bank to moderately sloping overbank

DS right: $\quad$ Steep channel bank to valley wall

US left: $\quad$ Steep channel bank to moderately sloping overbank

US right: $\quad$ Steep channel bank to moderately sloping overbank

\section{Description of the Channel}

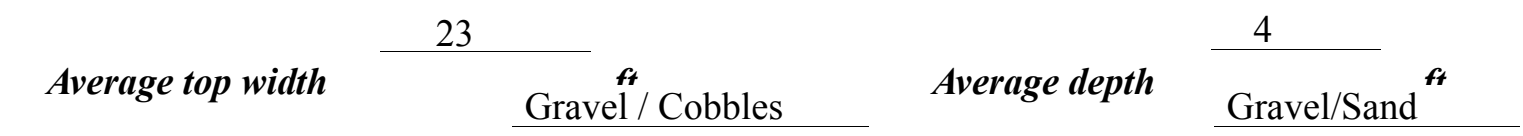

Predominant bed material

Bank material Sinuous but stable

with semi-allúvial channel boundaries.

$07 / 18 / 96$

Vegetative co 1 Trees and brush

DS left: $\quad$ Trees and brush

DS right: $\quad$ Brush and tall grasses

US left: $\quad$ Brush and tall grasses

US right: $\quad$ Y

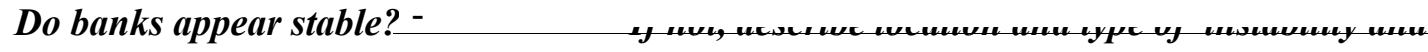

date of observatton.

None, 07/18/96.

Describe any obstructions in channel and date of observation. 


\section{Hydrology}

Drainage area $\stackrel{2.85}{\mathbf{m i}} \mathbf{m}^{2}$

Percentage of drainage area in physiographic provinces: (approximate)

Physiographic province/section New England/Green Mountain
Percent of drainage area 100
Is drainage area considered rural or urban?
Rural None.
urbanization: None.
Describe any significant

Is there a USGS gage on the stream of interest?

No

USGS gage description

USGS gage number

Gage drainage area $\mathrm{mi}^{2}$

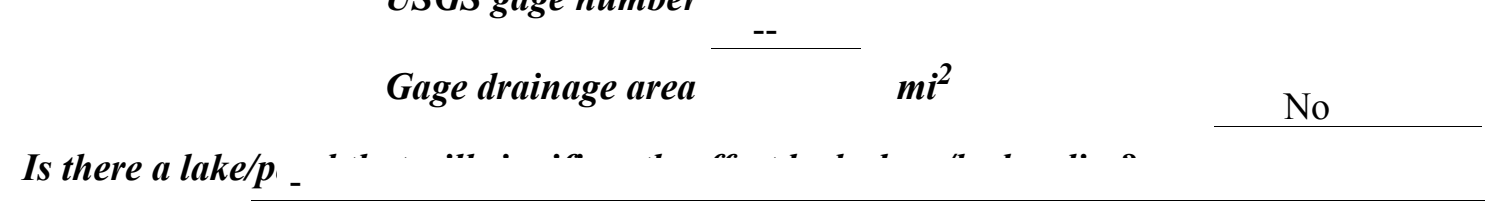

\begin{tabular}{ccrr}
660 & \multicolumn{2}{c}{ Calculated Discharges } & 900 \\
0100 & $f t^{3} / \mathrm{s}$ & $\mathbf{Q 5 0 0}$ & $\boldsymbol{f t} / \mathrm{s}$
\end{tabular}

The 100- and 500-year discharges are based on a

drainage area relationship.[(2.85/1.10)exp 0.7] with bridge number 33 in Moretown. Bridge number 33 crosses Cox Brook upstream of this site and has flood frequency estimates available from the VTAOT database. The drainage area above bridge number 33 is 1.1 square miles. The drainage area adjusted discharge values are within a range defined by several empirical flood frequency curves. (Benson, 1962; Johnson and Tasker, 1974; FHWA, 1983; Potter, 1957a\&b; Talbot, 1887) 


\section{Description of the Water-Surface Profile Model (WSPRO) Analysis}

Datum for WSPRO analysis (USGS survey, sea level, VTAOT plans)

USGS survey

Datum tie between USGS survey and VTAOT plans

None.

Description of reference marks used to determine USGS datum. $\quad$ RM1 is a chiseled X on top of the upstream left wingwall (elev. $499.04 \mathrm{ft}$, arbitrary survey datum). RM2 is a chiseled X on top of the upstream right curbing (elev. $500.71 \mathrm{ft}$, arbitrary survey datum). RM3 is a nail in the telephone pole on the right bank, pole \#103 (elev. $504.78 \mathrm{ft}$, arbitrary survey datum).

\section{Cross-Sections Used in WSPRO Analysis}

\begin{tabular}{cccl}
\hline${ }^{1}$ Cross-section & $\begin{array}{c}\text { Section } \\
\text { Reference } \\
\text { Distance } \\
\text { (SRD) in feet }\end{array}$ & $\begin{array}{c}{ }^{2} \text { Cross-section } \\
\text { development }\end{array}$ & \multicolumn{1}{c}{ Comments } \\
\hline EXITX & -21 & 1 & $\begin{array}{l}\text { Exit section } \\
\text { Downstream Full-valley } \\
\text { section (Templated from } \\
\text { EXITL) }\end{array}$ \\
BRIDG & 0 & 2 & $\begin{array}{l}\text { Bridge section } \\
\text { RDWAY }\end{array}$ \\
APPRO & 15 & 1 & $\begin{array}{l}\text { Road Grade section } \\
\text { Modelled Approach sec- } \\
\text { tion (Templated from } \\
\text { APTEM) }\end{array}$ \\
APTEM & 48 & 2 & $\begin{array}{l}\text { Approach section as sur- } \\
\text { veyed (Used as a tem- } \\
\text { plate) }\end{array}$ \\
\hline
\end{tabular}

${ }^{1}$ For location of cross-sections see plan-view sketch included with Level I field form, Appendix E. For more detail on how cross-sections were developed see WSPRO input file. 


\section{Data and Assumptions Used in WSPRO Model}

Hydraulic analyses of the reach were done by use of the Federal Highway Administration's WSPRO step-backwater computer program (Shearman and others, 1986, and Shearman, 1990). The analyses reported herein reflect conditions existing at the site at the time of the study. Furthermore, in the development of the model it was necessary to assume no accumulation of debris or ice at the site. Results of the hydraulic model are presented in the Bridge Hydraulic Summary, Appendix B, and figure 7.

Channel roughness factors (Manning's “ $n$ ”) used in the hydraulic model were estimated using field inspections at each cross section following the general guidelines described by Arcement and Schneider (1989). Final adjustments to the values were made during the modelling of the reach. Channel " $n$ " values for the reach ranged from 0.040 to 0.055 and overbank " $n$ " values ranged from 0.043 to 0.070 .

Normal depth at the exit section (EXITX) was assumed as the starting water surface. This depth was computed by use of the slope-conveyance method outlined in the user's manual for WSPRO (Shearman, 1990). The slope used was $0.0182 \mathrm{ft} / \mathrm{ft}$ which was estimated from the topographic map (U.S. Geological Survey, 1980).

The surveyed approach section (APTEM) was moved along the approach channel slope $(0.0053 \mathrm{ft} / \mathrm{ft})$ to establish the modelled approach section (APPRO), one bridge length upstream of the upstream face as recommended by Shearman and others (1986). This location also provides a consistent method for determining scour variables. 


\section{Bridge Hydraulics Summary}

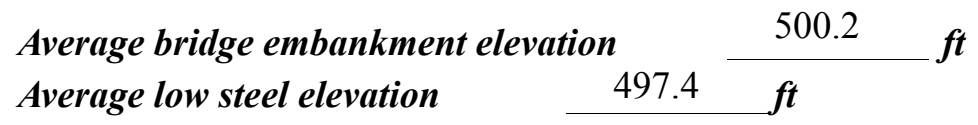

$$
\text { 100-year discharge } \quad 660 \quad \mathrm{ft}^{3} / \mathrm{s}
$$

Water-surface elevation in bridge opening $\quad \begin{array}{lll}497.8 \quad f t \\ \end{array}$

Road overtopping? ___ Yes Discharge over road __ 150 $\mathrm{ft}^{3} / \mathrm{s}$

\begin{tabular}{llll} 
Area of flow in bridge opening & $70 \quad \mathrm{ft}^{2}$ \\
\cline { 2 - 3 } Average velocity in bridge opening & 7.3 & $\mathrm{ft} / \mathrm{s}$
\end{tabular}

Maximum WSPRO tube velocity at bridge $\begin{array}{lll}8.6 & \mathrm{ft} / \mathrm{s}\end{array}$

Water-surface elevation at Approach section with bridge 499.6

Water-surface elevation at Approach section without bridge $\quad \overline{498.9}$

Amount of backwater caused by bridge $\quad 0.7 \quad$ it

500-year discharge $\quad 900 \quad \mathrm{ft}^{3} / \mathrm{s}$

Water-surface elevation in bridge opening $\quad 497.8 \mathrm{ft}$

Road overtopping? ___ Yes Discharge over road _ $390, \ldots$

Area of flow in bridge opening $\quad 70 \quad \mathrm{ft}^{2}$

Average velocity in bridge opening $7.1 \mathrm{ft} / \mathrm{s}$

Maximum WSPRO tube velocity at bridge 8.5 _

Water-surface elevation at Approach section with bridge 500.1

Water-surface elevation at Approach section without bridge $\quad 499.4$

Amount of backwater caused by bridge $\quad 0.7$.t

Incipient overtopping discharge $\quad 560 \quad \mathrm{ft}^{3} / \mathrm{s}$

Water-surface elevation in bridge opening $497.7 \quad t$

Area of flow in bridge opening

Average velocity in bridge opening

$70 \quad \mathrm{ft}^{2}$

Maximum WSPRO tube velocity at bridge $\quad 9.3 \mathrm{ft} / \mathrm{s}$

Water-surface elevation at Approach section with bridge

Water-surface elevation at Approach section without bridge

499.1

Amount of backwater caused by bridge $\quad 0.7$.t

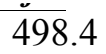




\section{Scour Analysis Summary}

\section{Special Conditions or Assumptions Made in Scour Analysis}

Scour depths were computed using the general guidelines described in Hydraulic Engineering Circular 18 (Richardson and others, 1995). Scour depths were calculated assuming an infinite depth of erosive material and a homogeneous particle-size distribution. The results of the scour analysis are presented in tables 1 and 2 and a graph of the scour depths is presented in figure 8 .

At this site, all modelled discharges resulted in submerged orifice flow. Contraction scour at bridges with orifice flow is best estimated by use of the Chang pressure-flow scour equation (oral communication, J. Sterling Jones, October 4, 1996). Thus, contraction scour for these discharges was computed by use of the Chang equation (Richardson and others, 1995, p. 145-146). The streambed armoring depths computed suggest that armoring will not limit the depth of contraction scour.

For comparison, contraction scour for the discharges resulting in orifice flow was also computed by use of the Laursen clear-water contraction scour equation and the Umbrell pressure-flow equation (Richardson and others, 1995, p. 144) and presented in Appendix F.

Abutment scour for the right abutment was computed by use of the Froehlich equation (Richardson and others, 1995, p. 48, equation 28). Variables for the Froehlich equation include the Froude number of the flow approaching the embankments, the length of the embankment blocking flow, and the depth of flow approaching the embankment less any roadway overtopping.

Scour at the left abutment was computed by use of the HIRE equation (Richardson and others, 1995, p. 49, equation 29) because the HIRE equation is recommended when the length to depth ratio of the embankment blocking flow exceeds 25 . The variables used by the HIRE abutment-scour equation are defined the same as those defined for the Froehlich abutment-scour equation. 


\section{Scour Results}

100-yr discharge 500-yr discharge

(Scour depths in feet)

Main channel

Live-bed scour

Clear-water scour

Depth to armoring

Left overbank

Right overbank

Local scour:

Abutment scour

Left abutment

Right abutment

Pier scour

Pier 1

Pier 2

Pier 3

\section{Abutments:}

Left abutment

Right abutment

Piers:

Pier 1

Pier 2

Incipient overtopping discharge
3.0

$3.5-$
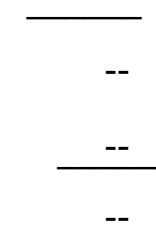

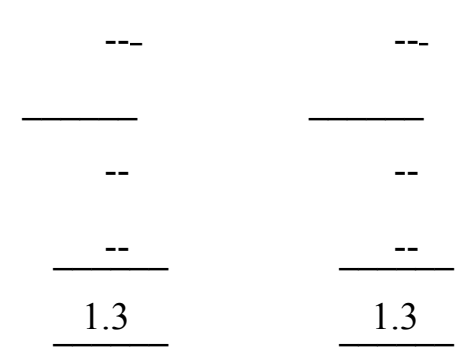

3.9

\section{Riprap Sizing}

Incipient overtopping 100-yrdischarge 500-yrdischarge discharge

1.5

1.5
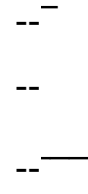
( $D_{50}$ in feet)
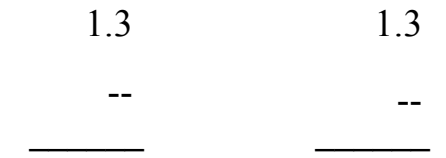

$--$

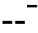

$--$ 


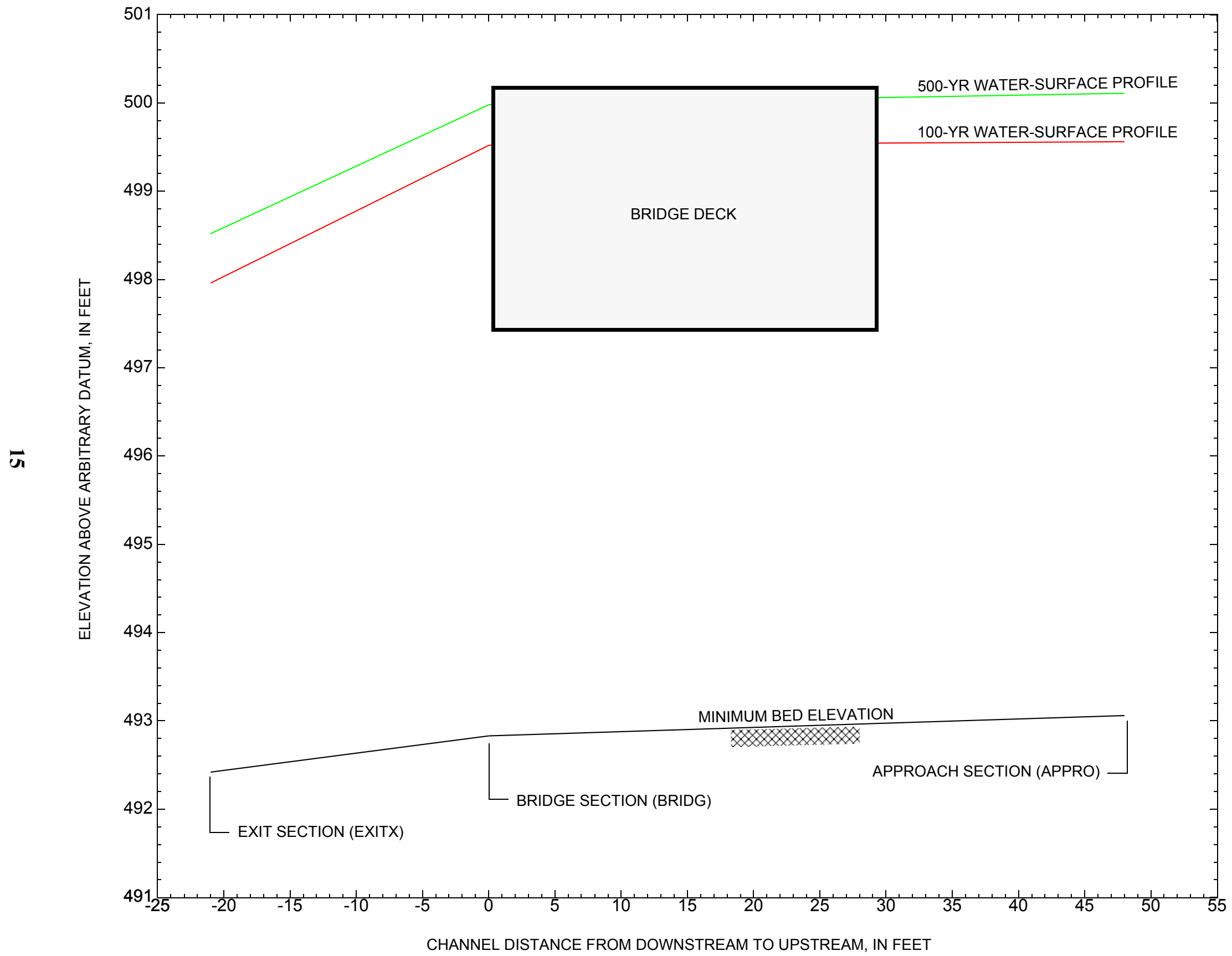

Figure 7. Water-surface profiles for the 100- and 500-yr discharges at structure MORETH00010021 on Town Highway 1, crossing Cox Brook, Moretown, Vermont. 


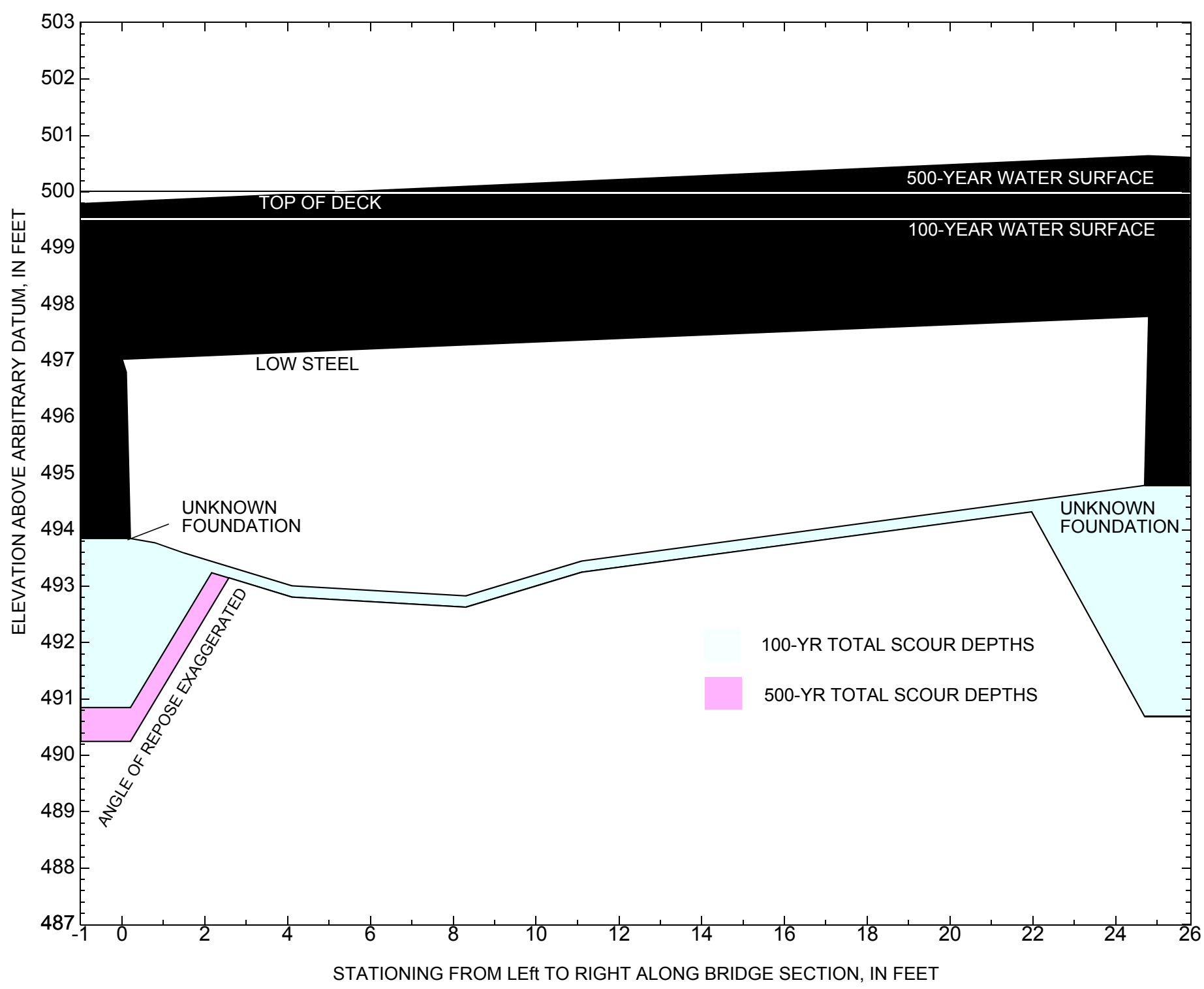

Figure 8. Scour elevations for the 100-yr and 500-yr discharges at structure MORETH00010021 on Town Highway 1, crossing Cox Brook, Moretown, Vermont. 
Table 1. Remaining footing/pile depth at abutments for the 100-year discharge at structure MORETH00010021 on Town Highway 1, crossing Cox Brook, Moretown, Vermont.

[VTAOT, Vermont Agency of Transportation; --,no data]

\begin{tabular}{|c|c|c|c|c|c|c|c|c|c|c|c|}
\hline Description & Station $^{1}$ & $\begin{array}{l}\text { VTAOT } \\
\text { minimum } \\
\text { low-chord } \\
\text { elevation } \\
\text { (feet) }\end{array}$ & $\begin{array}{c}\text { Surveyed } \\
\text { minimum } \\
\text { low-chord } \\
\text { elevation } \\
\text { (feet) }\end{array}$ & $\begin{array}{c}\text { Bottom of } \\
\text { footing/pile } \\
\text { elevation } \\
\text { (feet) }\end{array}$ & $\begin{array}{l}\text { Channel } \\
\text { elevation at } \\
\text { abutment/ } \\
\text { pier }^{2} \\
\text { (feet) }\end{array}$ & $\begin{array}{l}\text { Contraction } \\
\text { scour depth } \\
\text { (feet) }\end{array}$ & $\begin{array}{l}\text { Abutment } \\
\text { scour } \\
\text { depth } \\
\text { (feet) }\end{array}$ & $\begin{array}{l}\text { Pier } \\
\text { scour } \\
\text { depth } \\
\text { (feet) }\end{array}$ & $\begin{array}{l}\text { Depth of } \\
\text { total scour } \\
\text { (feet) }\end{array}$ & $\begin{array}{c}\text { Elevation of } \\
\text { scour }^{2} \\
\text { (feet) }\end{array}$ & $\begin{array}{c}\text { Remaining } \\
\text { footing/pile } \\
\text { depth } \\
\text { (feet) }\end{array}$ \\
\hline \multicolumn{12}{|c|}{100 -yr. discharge is 660 cubic-feet per second } \\
\hline Left abutment & 0.0 & -- & 497.0 & -- & 493.8 & 0.2 & 2.8 & -- & 3.0 & 490.8 & -- \\
\hline Right abutment & 24.8 & -- & 497.8 & -- & 494.8 & 0.2 & 4.0 & -- & 4.2 & 490.6 & -- \\
\hline
\end{tabular}

1.Measured along the face of the most constricting side of the bridge.

2.Arbitrary datum for this study.

Table 2. Remaining footing/pile depth at abutments for the 500-year discharge at structure MORETH00010021 on Town Highway 1, crossing Cox Brook, Moretown, Vermont. [VTAOT, Vermont Agency of Transportation; --, no data]

\begin{tabular}{|c|c|c|c|c|c|c|c|c|c|c|c|}
\hline Description & Station $^{1}$ & $\begin{array}{l}\text { VTAOT } \\
\text { minimum } \\
\text { low-chord } \\
\text { elevation } \\
\text { (feet) }\end{array}$ & $\begin{array}{l}\text { Surveyed } \\
\text { minimum } \\
\text { low-chord } \\
\text { elevation } \\
\text { (feet) }\end{array}$ & $\begin{array}{c}\text { Bottom of } \\
\text { footing/pile } \\
\text { elevation }{ }^{2} \\
\text { (feet) }\end{array}$ & $\begin{array}{c}\text { Channel } \\
\text { elevation at } \\
\text { abutment/ } \\
\text { pier }^{2} \\
\text { (feet) }\end{array}$ & $\begin{array}{l}\text { Contraction } \\
\text { scour depth } \\
\text { (feet) }\end{array}$ & $\begin{array}{l}\text { Abutment } \\
\text { scour } \\
\text { depth } \\
\text { (feet) }\end{array}$ & $\begin{array}{l}\text { Pier } \\
\text { scour } \\
\text { depth } \\
\text { (feet) }\end{array}$ & $\begin{array}{l}\text { Depth of } \\
\text { total scour } \\
\text { (feet) }\end{array}$ & $\begin{array}{c}\text { Elevation of } \\
\text { scour }^{2} \\
\text { (feet) }\end{array}$ & $\begin{array}{c}\text { Remaining } \\
\text { footing/pile } \\
\text { depth } \\
\text { (feet) }\end{array}$ \\
\hline \multicolumn{12}{|c|}{500 -yr. discharge is 900 cubic-feet per second } \\
\hline Left abutment & 0.0 & -- & 497.0 & -- & 493.8 & 0.2 & 3.4 & -- & 3.6 & 490.2 & -- \\
\hline Right abutment & 24.8 & -- & 497.8 & -- & 494.8 & 0.2 & 3.9 & -- & 4.1 & 490.7 & -- \\
\hline
\end{tabular}

1.Measured along the face of the most constricting side of the bridge.

2.Arbitrary datum for this study. 


\section{SELECTED REFERENCES}

Arcement, G.J., Jr., and Schneider, V.R., 1989, Guide for selecting Manning's roughness coefficients for natural channels and flood plains:

U.S. Geological Survey Water-Supply Paper 2339, 38 p.

Barnes, H.H., Jr., 1967, Roughness characteristics of natural channels: U.S. Geological Survey Water-Supply Paper 1849,213 p.

Benson, M. A., 1962, Factors Influencing the Occurrence of Floods in a Humid Region of Diverse Terrain: U.S. Geological Survey WaterSupply Paper 1580-B, 64 p.

Brown, S.A. and Clyde, E.S., 1989, Design of riprap revetment: Federal Highway Administration Hydraulic Engineering Circular No. 11, Publication FHWA-IP-89-016, 156 p.

Federal Highway Administration, 1983, Runoff estimates for small watersheds and development of sound design: Federal Highway Administration Report FHWA-RD-77-158.

Federal Highway Administration, 1993, Stream Stability and Scour at Highway Bridges: Participant Workbook: Federal Highway Administration Report FHWA-HI-91-011.

Froehlich, D.C., 1989, Local scour at bridge abutments in Ports, M.A., ed., Hydraulic Engineering--Proceedings of the 1989 National Conference on Hydraulic Engineering: New York, American Society of Civil Engineers, p. 13-18.

Hayes, D.C.,1993, Site selection and collection of bridge-scour data in Delaware, Maryland, and Virginia: U.S. Geological Survey WaterResources Investigation Report 93-4017, 23 p.

Johnson, C.G. and Tasker, G.D.,1974, Progress report on flood magnitude and frequency of Vermont streams: U.S. Geological Survey OpenFile Report 74-130, 37 p.

Lagasse, P.F., Schall, J.D., Johnson, F., Richardson, E.V., Chang, F., 1995, Stream Stability at Highway Structures: Federal Highway Administration Hydraulic Engineering Circular No. 20, Publication FHWA-IP-90-014, 144 p.

Laursen, E.M., 1960, Scour at bridge crossings: Journal of the Hydraulics Division, American Society of Civil Engineers, v. 86, no. HY2, p. 39-53.

Potter, W. D., 1957a, Peak rates of runoff in the Adirondack, White Mountains, and Maine woods area, Bureau of Public Roads

Potter, W. D., 1957b, Peak rates of runoff in the New England Hill and Lowland area, Bureau of Public Roads

Richardson, E.V. and Davis, S.R., 1995, Evaluating scour at bridges: Federal Highway Administration Hydraulic Engineering Circular No. 18, Publication FHWA-IP-90-017, 204 p.

Richardson, E.V., Simons, D.B., and Julien, P.Y., 1990, Highways in the river environment: Federal Highway Administration Publication FHWA-HI-90-016.

Ritter, D.F., 1984, Process Geomorphology: W.C. Brown Co., Debuque, Iowa, 603 p.

Shearman, J.O., 1990, User's manual for WSPRO--a computer model for water surface profile computations: Federal Highway Administration Publication FHWA-IP-89-027, 187 p.

Shearman, J.O., Kirby, W.H., Schneider, V.R., and Flippo, H.N., 1986, Bridge waterways analysis model; research report: Federal Highway Administration Publication FHWA-RD-86-108, 112 p.

Talbot, A.N., 1887, The determination of water-way for bridges and culverts.

U.S. Department of Transportation, 1993, Stream stability and scour at highway bridges, Participant Workbook: Federal Highway Administration Publication FHWA HI-91-011.

U.S. Geological Survey, 1980, Northfield, Vermont 7.5 Minute Series quadrangle map: U.S. Geological Survey Topographic Maps, Photoinspected 1983, Scale 1:24,000. 


\section{APPENDIX A: \\ WSPRO INPUT FILE}




\section{WSPRO INPUT FILE}

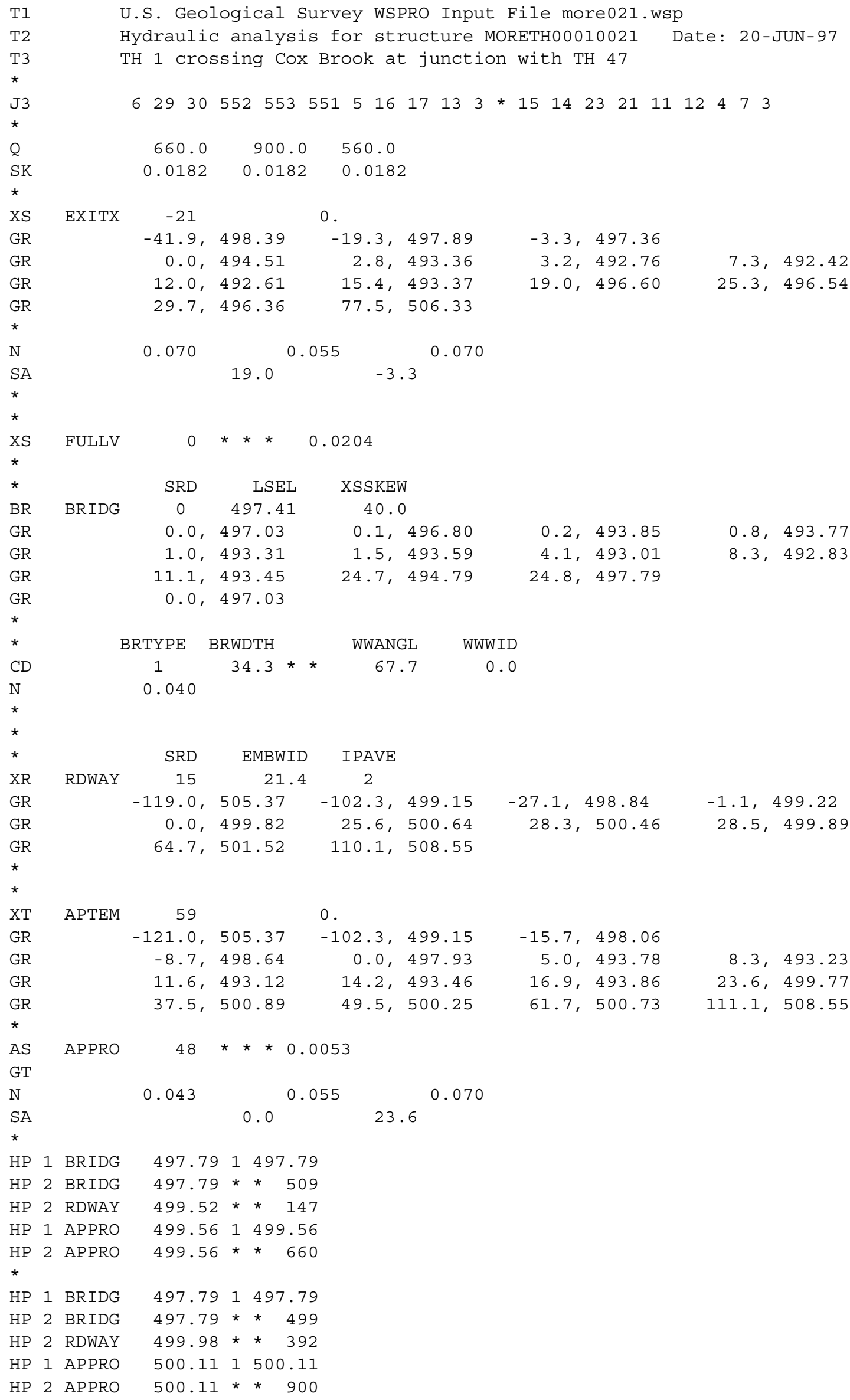




\section{APPENDIX B: \\ WSPRO OUTPUT FILE}




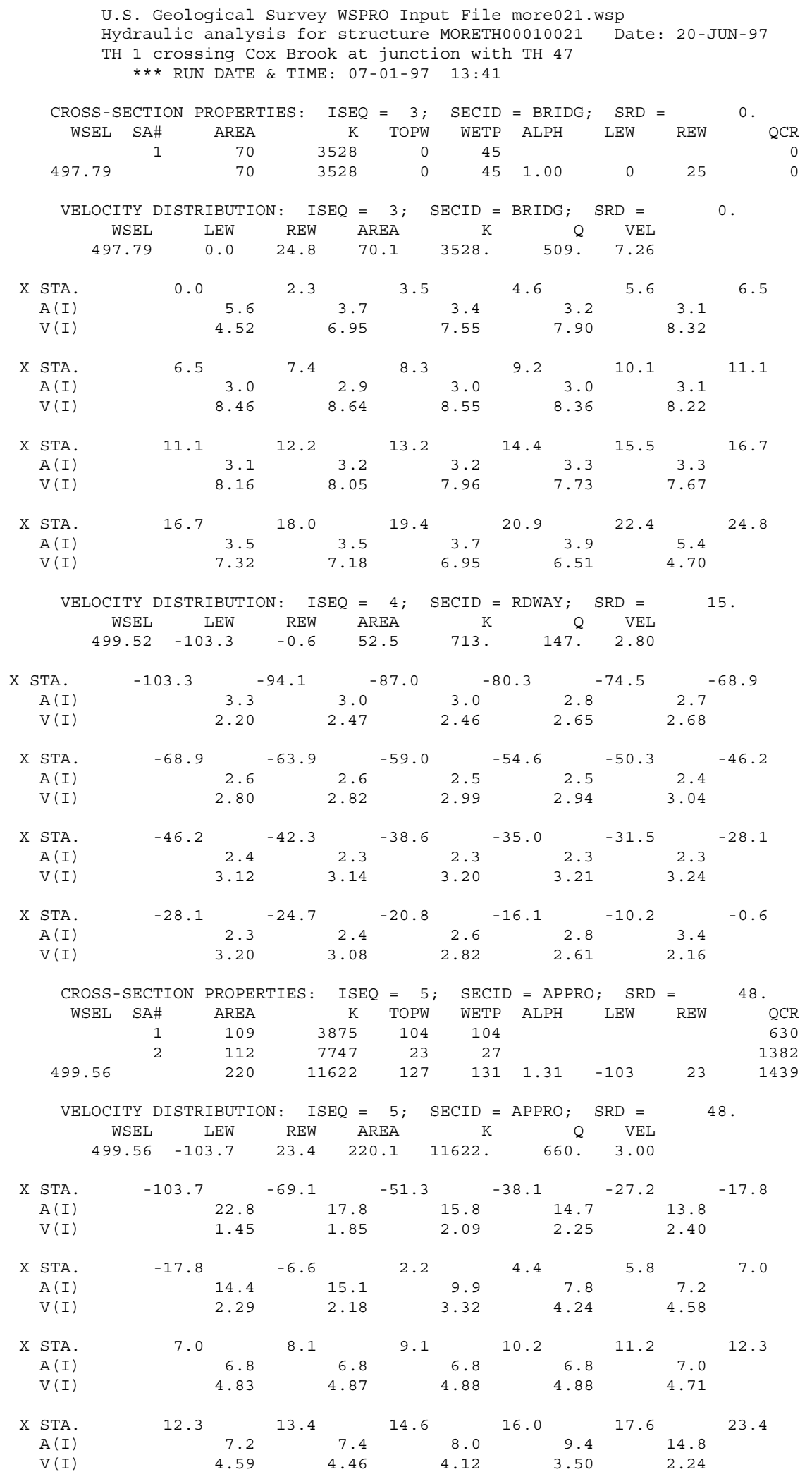


WSPRO OUTPUT FILE (continued)

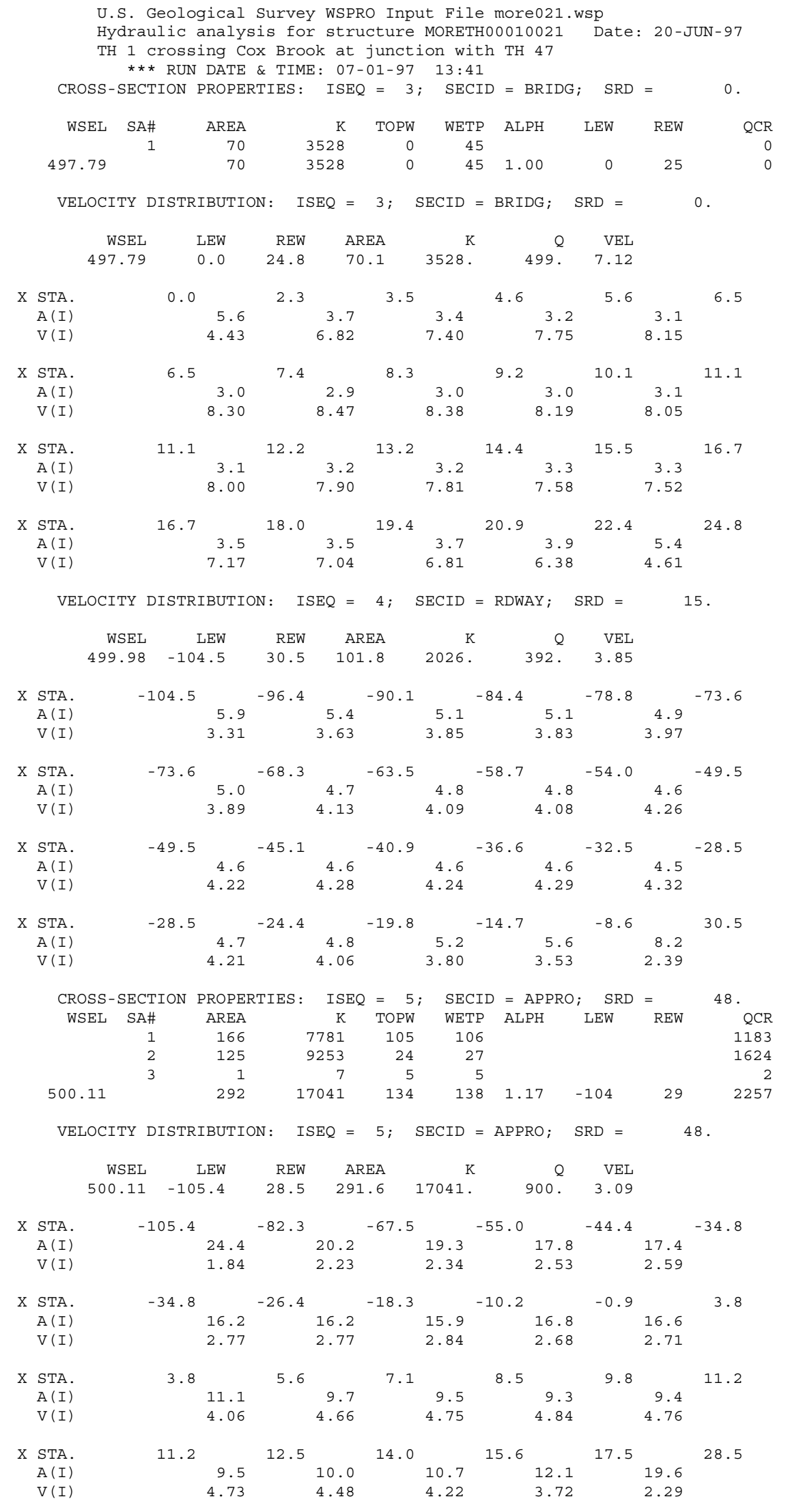


WSPRO OUTPUT FILE (continued)

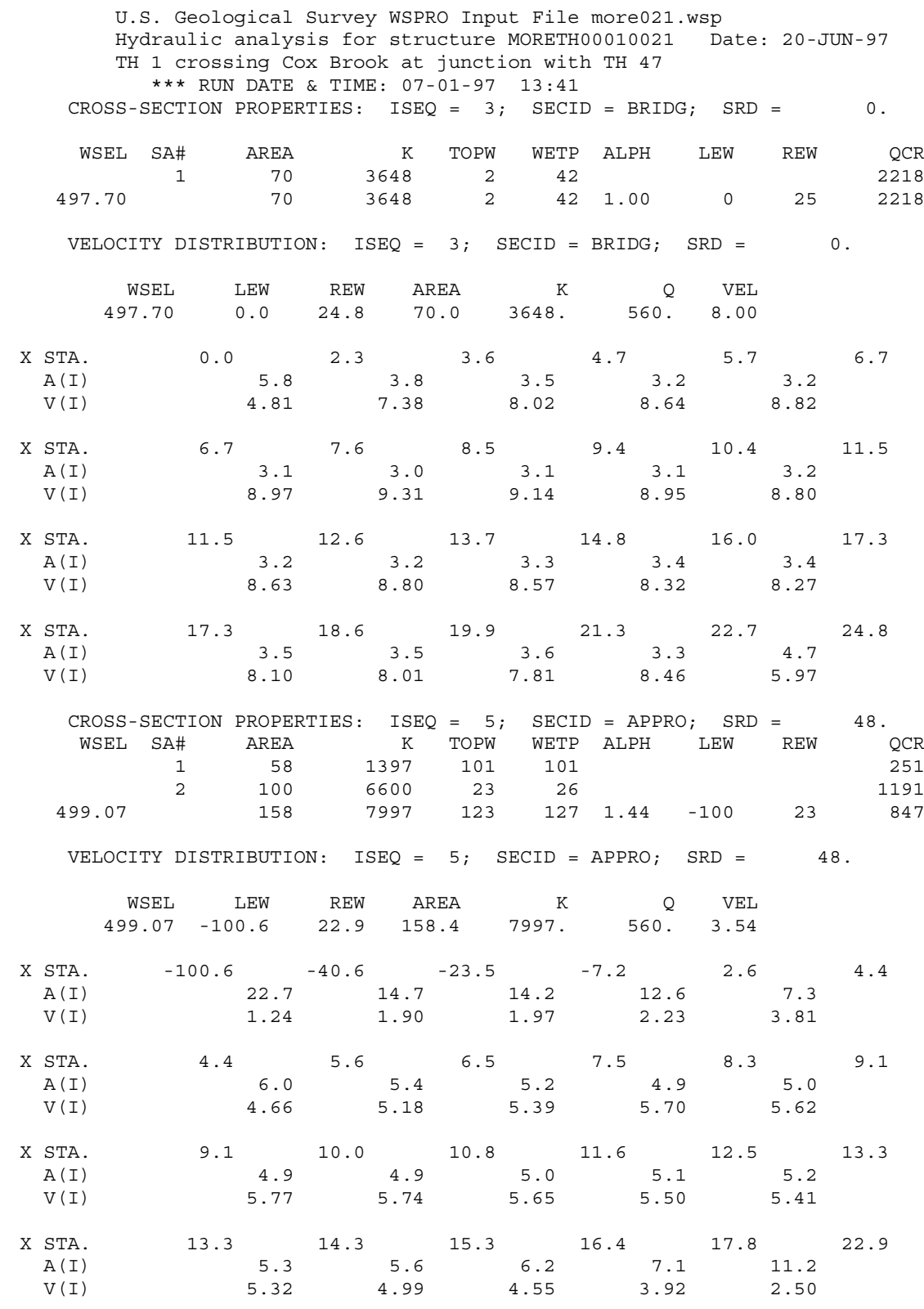


WSPRO OUTPUT FILE (continued)

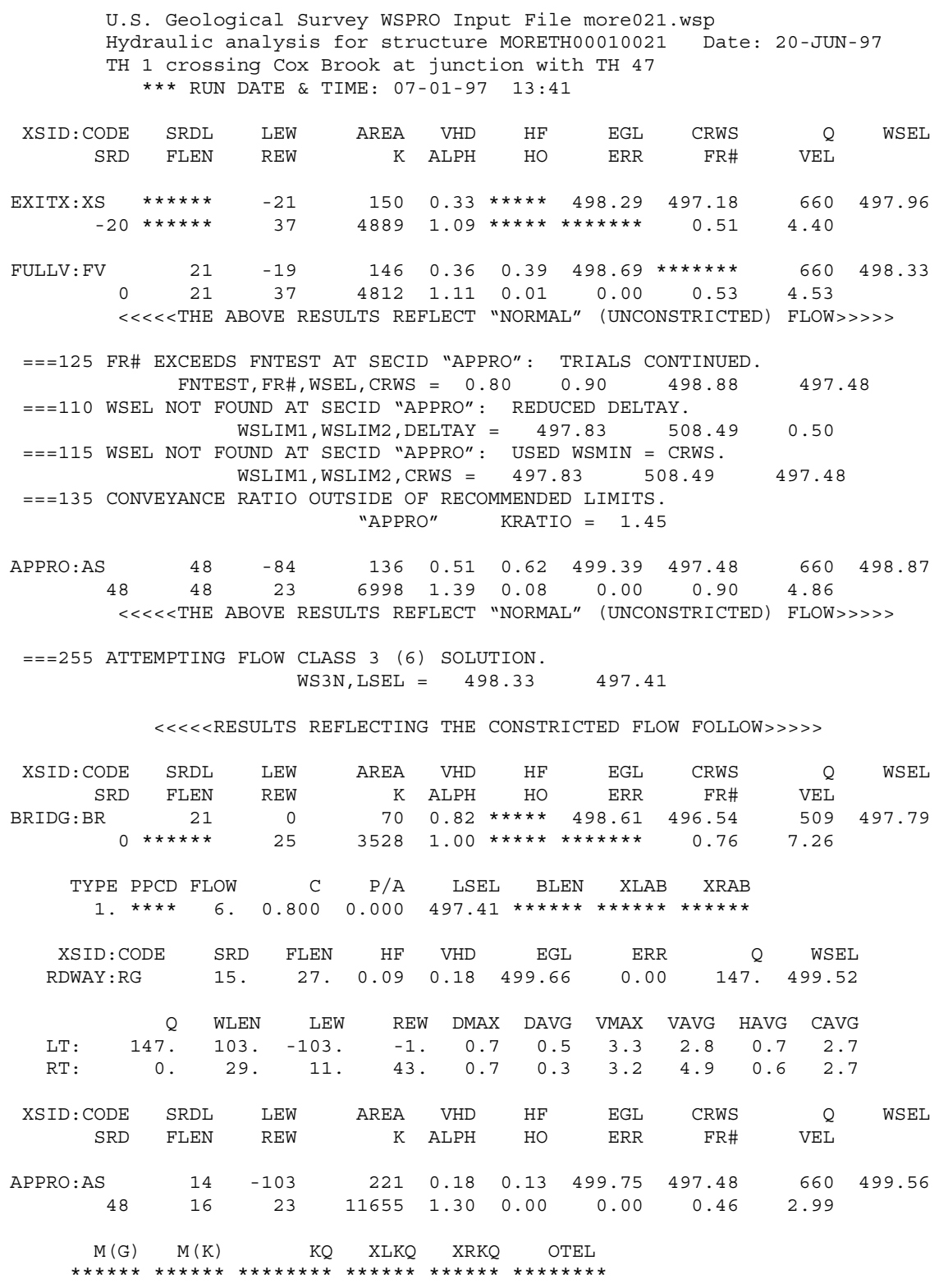

$<<<<$ END OF BRIDGE COMPUTATIONS $>>>>>$

FIRST USER DEFINED TABLE.

\begin{tabular}{lrrrrrrrr} 
XSID $:$ CODE & \multicolumn{1}{c}{ SRD } & LEW & REW & $Q$ & K & AREA & VEL & WSEL \\
EXITX $:$ XS & -21. & -22. & 37. & 660. & 4889. & 150. & 4.40 & 497.96 \\
FULLV $:$ FV & 0. & -20. & 37. & 660. & 4812. & 146. & 4.53 & 498.33 \\
BRIDG $:$ BR & 0. & 0. & 25. & 509. & 3528. & 70. & 7.26 & 497.79 \\
RDWAY : RG & $15 . * * * * * *$ & 147. & 147. & 0. & 0. & 2.00 & 499.52 \\
APPRO $:$ AS & 48. & -104. & 23. & 660. & 11655. & 221. & 2.99 & 499.56
\end{tabular}

SECOND USER DEFINED TABLE.

$\begin{array}{lccccccccc}\text { XSID : CODE } & \text { CRWS } & \text { FR\# } & \text { YMIN } & \text { YMAX } & \text { HF } & \text { HO } & \text { VHD } & \text { EGL } & \text { WSEL } \\ \text { EXITX:XS } & 497.18 & 0.51 & 492.42 & 506.33 * * * * * * * * * * & 0.33 & 498.29 & 497.96 \\ \text { FULLV : FV } & * * * * * * * * & 0.53 & 492.85 & 506.76 & 0.39 & 0.01 & 0.36 & 498.69 & 498.33 \\ \text { BRIDG : BR } & 496.54 & 0.76 & 492.83 & 497.79 * * * * * * * * * * * & 0.82 & 498.61 & 497.79 \\ \text { RDWAY : RG } & * * * * * * * * * * * * * * * & 498.84 & 508.55 & 0.09 * * * * * * & 0.18 & 499.66 & 499.52 \\ \text { APPRO : AS } & 497.48 & 0.46 & 493.06 & 508.49 & 0.13 & 0.00 & 0.18 & 499.75 & 499.56\end{array}$


WSPRO OUTPUT FILE (continued)

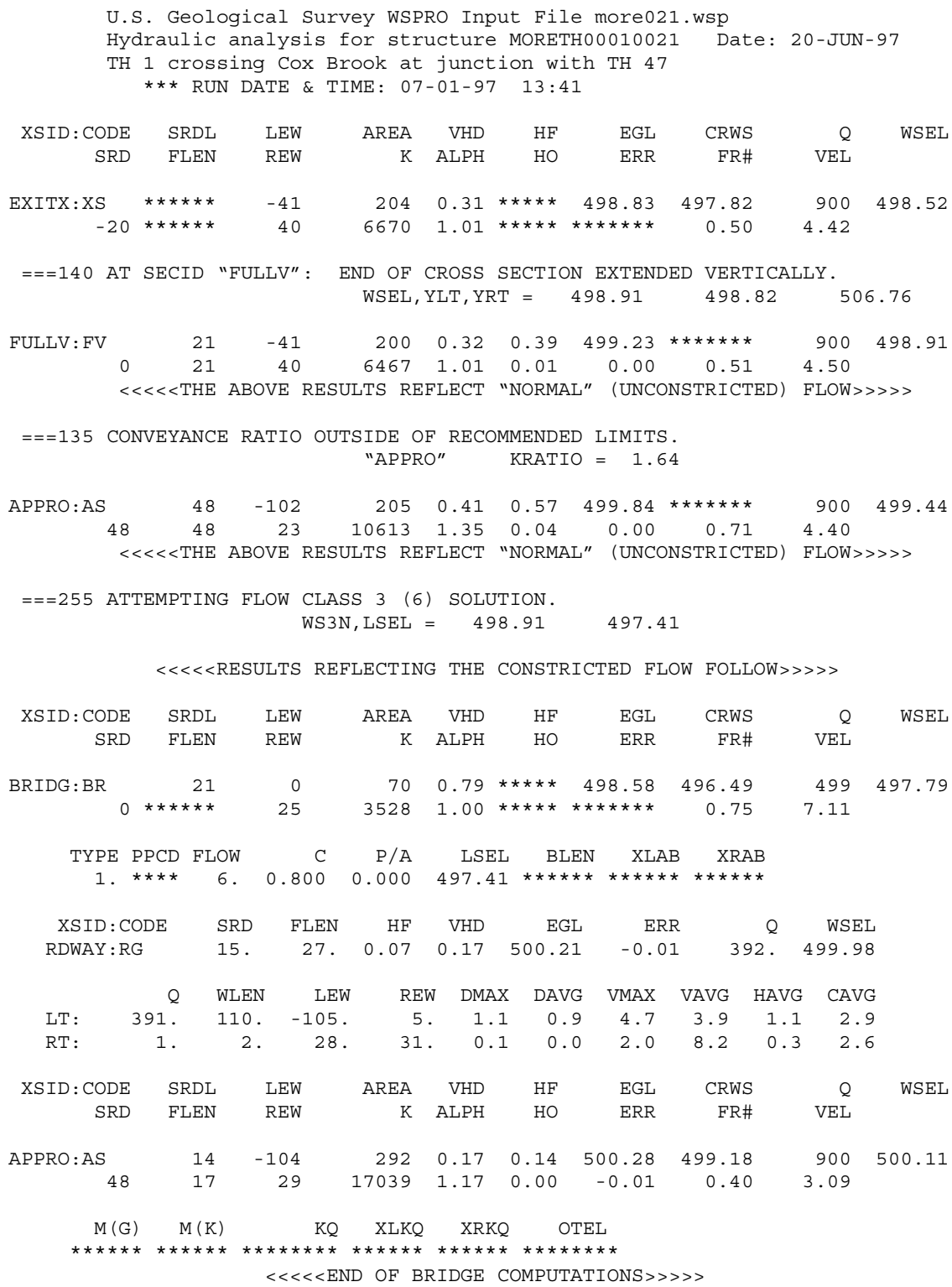


WSPRO OUTPUT FILE (continued)

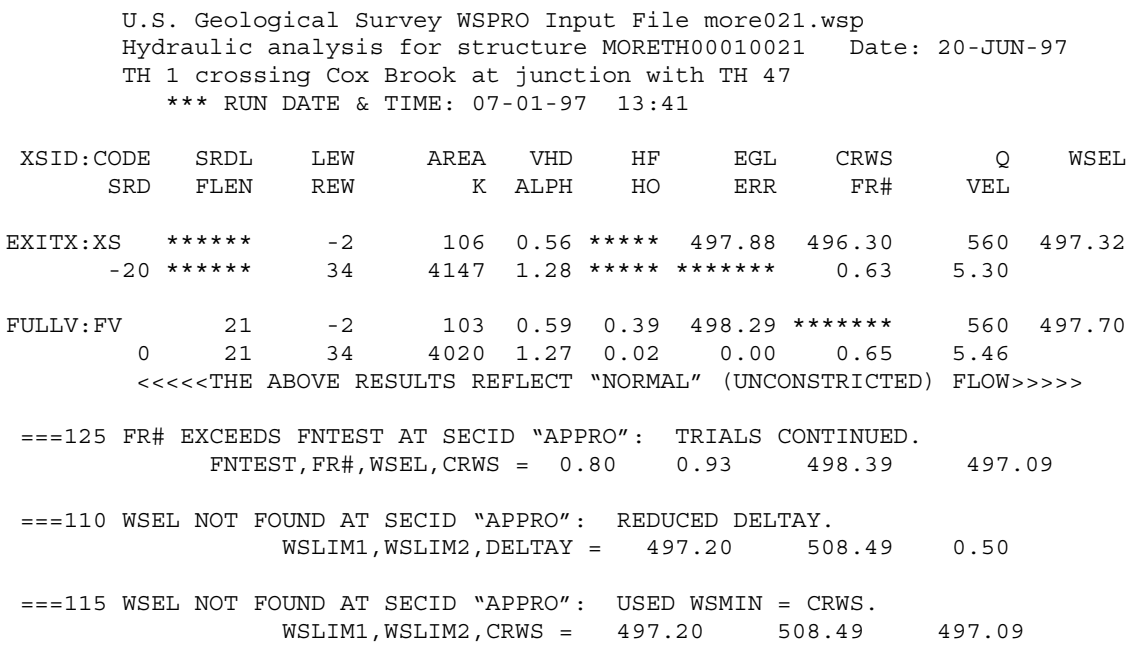

FIRST USER DEFINED TABLE.

\begin{tabular}{lrrrrrrrr} 
XSID $:$ CODE & SRD & LEW & REW & $Q$ & K & AREA & VEL & WSEL \\
EXITX : XS & -21. & -3. & 34. & 560. & 4147. & 106. & 5.30 & 497.32 \\
FULLV : FV & 0. & -3. & 34. & 560. & 4020. & 103. & 5.46 & 497.70 \\
BRIDG : BR & 0. & 0. & 25. & 549. & 3645. & 70. & 7.84 & 497.70 \\
RDWAY : RG & \multicolumn{2}{c}{$15 . * * \star * * * * * * * * *$} & 0. & 0. & 0. & $2.00 * * * * * * *$ \\
APPRO : AS & 48. & -101. & 23. & 560. & 8008. & 159. & 3.53 & 499.07
\end{tabular}

SECOND USER DEFINED TABLE.

\begin{tabular}{|c|c|c|c|c|c|c|c|c|c|}
\hline XSID : CODE & CRWS & FR\# & YMIN & YMAX & $\mathrm{HF}$ & HO & VHD & EGL & WSEL \\
\hline EXITX:XS & 496.30 & 0.63 & 492.42 & $506.33 *$ & $* * * \star * * *$ & $\star * * * *$ & 0.56 & 497.88 & 497.32 \\
\hline FULLV : FV & $\star * \star * * * * *$ & 0.65 & 492.85 & 506.76 & 0.39 & 0.02 & 0.59 & 498.29 & 497.70 \\
\hline BRIDG : BR & 496.68 & 0.82 & 492.83 & 497.79 * & $k * * * * * *$ & 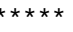 & 0.96 & 498.66 & 497.70 \\
\hline RDWAY : RG & 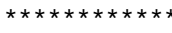 & 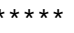 & 498.84 & $508.55 *$ & $k * * \star * * *$ & $\star \star \star \star \star *$ & 0.28 & 499.22 * & 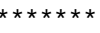 \\
\hline APPRO: AS & 497.09 & 0.66 & 493.06 & 508.49 & 0.16 & 0.00 & 0.28 & 499.35 & 499.07 \\
\hline
\end{tabular}




\section{APPENDIX C:}

\section{BED-MATERIAL PARTICLE-SIZE DISTRIBUTION}




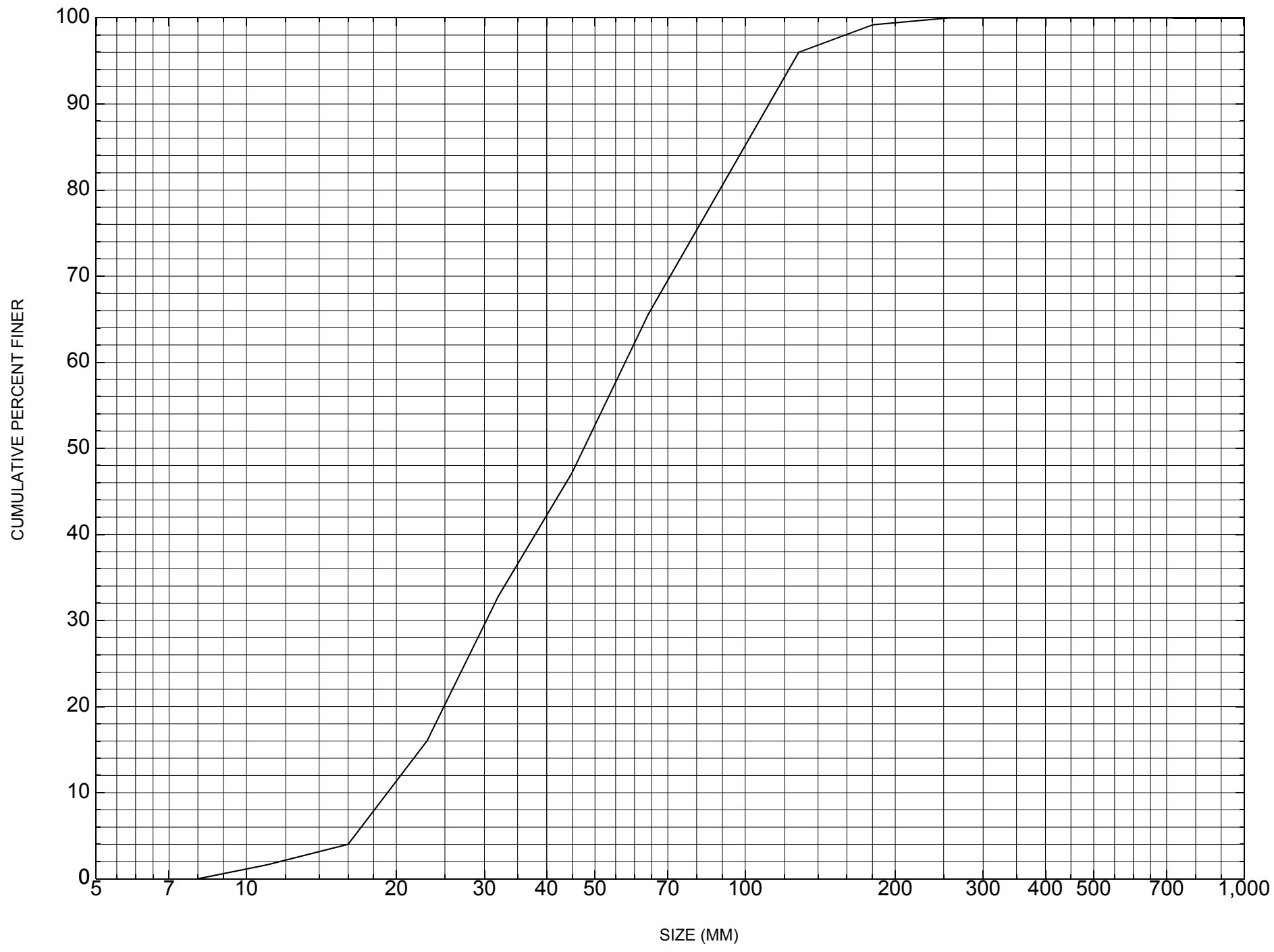

Appendix C. Bed material particle-size distribution for a pebble count in the channel approach of structure MORETH00010021, in Moretown, Vermont. 


\section{APPENDIX D: \\ HISTORICAL DATA FORM}




\section{Structure Number MORETH00010021}

\section{General Location Descriptive}

Data collected by (First Initial, Full last name) $\underline{\mathbf{L}}$. Medalie

Date $(M M / D D / Y Y) \_10 / 13 / \underline{95}$

Highway District Number (I - 2; nn) $\mathbf{0 6}$

Town (FIPS place code; I - 4; nnnnn) $\mathbf{4 6 2 2 5}$

Waterway (I - 6) COX BROOK

Route Number C2001

Topographic Map Northfield

Latitude (I - 16; nnnn.n) $\mathbf{4 4 1 2 5}$
County (FIPS county code; I - 3; nnn)

Mile marker (I - 11; nnn.nnn) $\mathbf{0 0 0 0 0 0}$

Road Name (I - 7): -

Vicinity (I - 9)@JCT W CL4 TH47

Hydrologic Unit Code: 2010003

Longitude (i - 17; nnnnn.n) 72419

\section{Select Federal Inventory Codes}

FHWA Structure Number (I - 8) $\mathbf{1 0 1 2 1 2 0 0 2 1 1 2 1 2}$

Maintenance responsibility $(I-21 ; n n) \quad \mathbf{0 3}$

Year built (I - 27; YYYY) 1954

Average daily traffic, ADT (I - 29; nnnnnn) 000200

Year of ADT (I - 30; YY) $\mathbf{9 2}$

Opening skew to Roadway $(I-34 ; n n) \quad \mathbf{4 2}$

Operational status $(I-41 ; X) \quad \mathbf{A}$

Structure type (I - 43; nnn) $\mathbf{3 0 2}$

Approach span structure type $(I-44 ; n n n) \quad \mathbf{0 0 0}$

Number of spans (I - 45; nnn) $\mathbf{0 0 1}$

Number of approach spans (I - 46; nnnn) $\mathbf{0 0 0 0}$

Comments:

According to the structural inspection report dated 7/8/94, deck consists of a gravel wearing surface, with a few small areas of bare concrete showing. There are cracks and spalls at the abutments. The LABUT US footing has separated from the stem. The US stem has moved 1.5" towards the stream. There are random cracks and displacement at the wingwalls. Some undermining is noted at the LABUT. Random spalls are noted mostly at the Labut and the left wingwall. Some settlement is noted at the LABUT US footing. There is heavy spalling and breaks at the LABUT footing. A settlement crack at beam 2 of the LABUT is $0.25 "$ wide at the top and 0.5 " at the bottom (Cont. pg. 33) 


\section{Bridge Hydrologic Data}

Is there hydrologic data available? $\underline{\mathbf{N}}$ if No, type ctrl-n $h \quad$ VTAOT Drainage area $\left(m i^{2}\right)$ : -

Terrain character:

Stream character \& type: -

Streambed material:

Discharge Data (cfs):

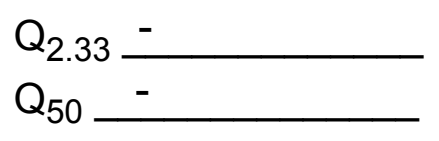

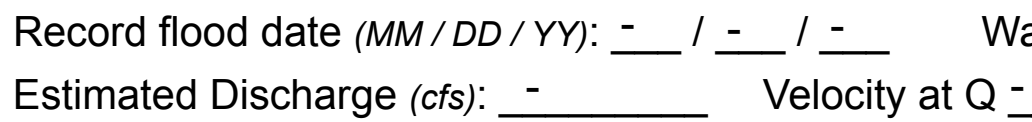

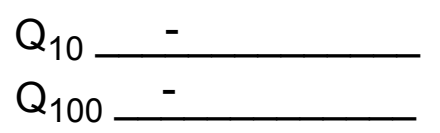

$\mathrm{Q}_{25}$

Water surface elevation $(f t):-$ $(\mathrm{ft} / \mathrm{s}):$

Ice conditions (Heavy, Moderate, Light) : -

Debris (Heavy, Moderate, Light):

The stage increases to maximum highwater elevation (Rapidly, Not rapidly):

The stream response is (Flashy, Not flashy):

Describe any significant site conditions upstream or downstream that may influence the stream's stage: -

Watershed storage area (in percent):

The watershed storage area is: - (1-mainly at the headwaters; 2- uniformly distributed; 3-immediatly upstream oi the site)

Water Surface Elevation Estimates for Existing Structure:

\begin{tabular}{|l|l|l|l|l|l|}
\hline Peak discharge frequency & $Q_{2.33}$ & $Q_{10}$ & $Q_{25}$ & $Q_{50}$ & $Q_{100}$ \\
Water surface elevation (ft)) & - & - & - & - & - \\
Velocity (ft/sec) & - & - & - & - & - \\
\hline
\end{tabular}

Long term stream bed changes: -

Is the roadway overtopped below the $Q_{100}$ ? (Yes, No, Unknown):

Frequency: -

Relief Elevation (ft):

Discharge over roadway at $Q_{100}\left(f^{3} / \mathrm{sec}\right)$ :

Are there other structures nearby? (Yes, No, Unknown): $\mathbf{N}$ Upstream distance (miles): Town: If No or Unknown, type ctrl-n os Highway No. : Structure No. : Year Built:

Clear span (ft): Clear Height (ft): Full Waterway $\left(f t^{2}\right)$ : 
Downstream distance (miles): Town: Year Built:

Highway No. : Structure No. : Structure Type:

Clear span $(f t):$ Clear Height $(f t)$ : Full Waterway $\left(f^{2}\right)$ :

Comments:

The LABUT US wingwall stem is displaced towards the stream. There is scour noted along the bottom of the downstream banks. There is a large gravel bar in front of the RABUT that extends $3 / 4$ of the way through the bridge. There are some dead trees and debris blocking the stream $50 \mathrm{ft}$ DS of the bridge. There is some stone fill just US of the LABUT wingwall along the bank. The LABUT is noted as having a poor subfooting. The streambed consists of sand and gravel with a few boulders. The stream takes a sharp turn into the structure.

\section{USGS Watershed Data}

Watershed Hydrographic Data

Drainage area $(D A)$

Watershed storage (ST)

Bridge site elevation

Main channel length 960

2.93 $10 \%$ channel length elevation $\mathrm{mi}^{2}$ 0 $\%$

Main channel slope

(S) 213.88 $\mathrm{ft} / \mathrm{mi}$ mi
Lake/pond/swamp area $\mathbf{0}$ $\mathrm{mi}^{2}$ Headwater elevation $1983 \quad \mathrm{ft}$ $\mathrm{ft} \quad 85 \%$ channel length elevation 1460 $\mathrm{ft}$

Watershed Precipitation Data

Average site precipitation in Average headwater precipitation in

Maximum 2yr-24hr precipitation event $(124,2)$ in

Average seasonal snowfall (Sn) $\mathrm{ft}$ 


\section{Bridge Plan Data}

Are plans available? $\underline{\mathbf{Y}}$ If no, type ctrl-n pl Date issued for construction (MM/YYYY):

Project Number

Minimum channel bed elevation:

Low superstructure elevation: USLAB DSLAB USRAB DSRAB Benchmark location description:

There is no benchmark information available.

Reference Point (MSL, Arbitrary, Other):

Datum (NAD27, NAD83, Other):

Foundation Type: 4

If 1: Footing Thickness

If 2: Pile Type:

If 3: Footing bottom elevation:

Is boring information available?

(1

(1-Spreadfooting; 2-Pile; 3- Gravity; 4-Unknown)

Footing bottom elevation: -

Foundation Material Type: $\mathbf{3}$ (1-regolith, 2-bedrock, 3-unknown)

Briefly describe material at foundation bottom elevation or around piles:

There is no foundation material information available.

Comments:

There is limited information in plans - no elevation data. The clear span and vertical height were measured from the plans. 


\section{Cross-sectional Data}

Is cross-sectional data available? $\mathbf{N}$ If no, type ctrl-n xs

Source (FEMA, VTAOT, Other)? -

Comments: There is no cross-section information available.

\begin{tabular}{|l|l|l|l|l|l|l|l|l|l|l|l|}
\hline Station & - & - & - & - & - & - & - & - & - & - & - \\
\hline Feature & - & - & - & - & - & - & - & - & - & - & - \\
\hline $\begin{array}{l}\text { Low cord } \\
\text { elevation }\end{array}$ & - & - & - & - & - & - & - & - & - & - & - \\
\hline $\begin{array}{l}\text { Bed } \\
\text { elevation }\end{array}$ & - & - & - & - & - & - & - & - & - & - & - \\
\hline $\begin{array}{l}\text { Low cord to } \\
\text { bed length }\end{array}$ & - & - & - & - & - & - & - & - & - & - & - \\
\hline Station & - & - & - & - & - & - & - & - & - & - & - \\
\hline Feature & - & - & - & - & - & - & - & - & - & - & - \\
\hline $\begin{array}{l}\text { Low cord } \\
\text { elevation }\end{array}$ & - & - & - & - & - & - & - & - & - & - & - \\
\hline $\begin{array}{l}\text { Bed } \\
\text { elevation }\end{array}$ & - & - & - & - & - & - & - & - & - & - & - \\
\hline $\begin{array}{l}\text { Low cord to } \\
\text { bed length }\end{array}$ & - & - & - & - & - & - & - & - & - & - & - \\
\hline
\end{tabular}

Source (FEMA, VTAOT, Other)?

Comments: -

\begin{tabular}{|l|l|l|l|l|l|l|l|l|l|l|l|}
\hline Station & - & - & - & - & - & - & - & - & - & - & - \\
\hline Feature & - & - & - & - & - & - & - & - & - & - & - \\
\hline $\begin{array}{l}\text { Low cord } \\
\text { elevation }\end{array}$ & - & - & - & - & - & - & - & - & - & - & - \\
\hline $\begin{array}{l}\text { Bed } \\
\text { elevation }\end{array}$ & - & - & - & - & - & - & - & - & - & - & - \\
\hline $\begin{array}{l}\text { Low cord to } \\
\text { bed length }\end{array}$ & - & - & - & - & - & - & - & - & - & - & - \\
\hline Station & - & - & - & - & - & - & - & - & - & - & - \\
\hline Feature & - & - & - & - & - & - & - & - & - & - & - \\
\hline $\begin{array}{l}\text { Low cord } \\
\text { elevation }\end{array}$ & - & - & - & - & - & - & - & - & - & - & - \\
\hline $\begin{array}{l}\text { Bed } \\
\text { elevation }\end{array}$ & - & - & - & - & - & - & - & - & - & - & - \\
\hline $\begin{array}{l}\text { Low cord to } \\
\text { bed length }\end{array}$ & - & - & - & - & - & - & - & - & - & - & - \\
\hline
\end{tabular}




\section{APPENDIX E: \\ LEVEL I DATA FORM}


U. S. Geological Survey

Bridge Field Data Collection and Processing Form

Qa/Qc Check by: $\underline{\mathbf{R B}}$ Date: 10/17/96

\section{Structure Number}

MORETH00010021

Computerized by: $\underline{\mathbf{R B}}$ Date: $10 / 31 / 96$

Reviewd by: LKS Date: $\underline{07 / 08 / 97}$

\section{A. General Location Descriptive}

1. Data collected by (First Initial, Full last name) $\underline{\mathbf{L}}$. Medalie

Date $(M M / D D / Y Y) \mathbf{0 7} / \underline{18} / \underline{1996}$

2. Highway District Number 06

Mile marker $\mathbf{0 0 0 0}$

County Washington (023)

Town Moretown (46225)

Waterway (I - 6) Cox Brook

Road Name Cox Brook Road

Route Number TH1

Hydrologic Unit Code: 2010003

3. Descriptive comments:

The bridge is located at the junction with TH 47.

\section{B. Bridge Deck Observations}
4. Surface cover... LBUS 6
RBUS 6
LBDS 6
RBDS 6
Overall 6

(2b us,ds,lb,rb: 1- Urban; 2- Suburban; 3- Row crops; 4- Pasture; 5- Shrub- and brushland; 6- Forest; 7- Wetland)
5. Ambient water surface... US $\underline{2}$
UB 1
DS $\underline{2}$
(1- pool; 2- riffle)

6. Bridge structure type 1 (1- single span; 2- multiple span; 3- single arch; 4- multiple arch; 5-cylindrical culvert; 6- box culvert; or 7- other)
7. Bridge length 29
(feet)
Span length $\underline{27}$
(feet)
Bridge width 21.4 (feet)

\section{Road approach to bridge:}
8. LB 0
RB 2
( 0 even, 1- lower, 2- higher)
9. LB_2
RB $\underline{2}$
(1- Paved, 2- Not paved)

10. Embankment slope (run / rise in feet / foot)

US left

US right

\begin{tabular}{|c|c|c|c|}
\hline \multicolumn{2}{|c|}{ Protection } & \multirow{2}{*}{ 13.Erosion } & 14.Severity \\
\hline 11.Type & 12.Cond. & $\mathbf{0}$ & - \\
\hline $\mathbf{0}$ & - & $\mathbf{0}$ & - \\
\hline $\mathbf{0}$ & - & $\mathbf{0}$ & - \\
\hline $\mathbf{0}$ & - & $\mathbf{0}$ & - \\
\hline $\mathbf{0}$ & - & $\mathbf{2}$ & $\mathbf{1}$ \\
\hline
\end{tabular}

Bank protection types: 0- none; 1- < 12 inches;

2- < 36 inches; 3- < 48 inches;

4- < 60 inches; 5- wall / artificial levee

Bank protection conditions: 1- good; 2- slumped;

3- eroded; 4- failed

Erosion: 0 - none; 1- channel erosion; 2 -

road wash; 3- both; 4- other

Erosion Severity: 0 - none; 1- slight; 2- moderate; 3- severe

\section{Channel approach to bridge (BF):}

15. Angle of approach: $\mathbf{2 5}$

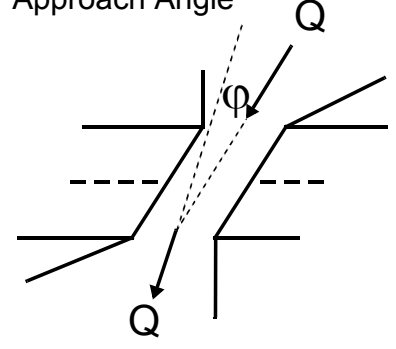

17. Channel impact zone 1:

Where? LB (LB, RB)

Range? 12 feet US

Channel impact zone 2:

Where? $(L B, R B)$

Range? - $\quad$ feet -

(US, UB, DS) to feet Impact Severity: 0- none to very slight; 1-Slight; 2- Moderate; 3- Severe

16. Bridge skew: 60 Bridge Skew Angle

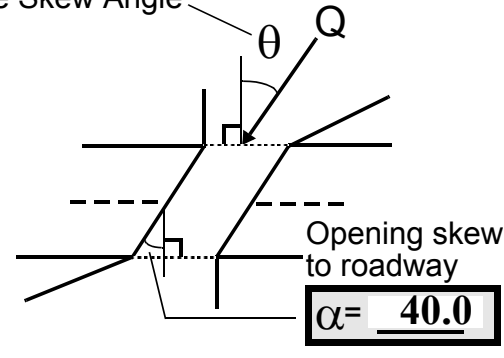

\section{Exist? $\mathbf{Y}(Y$ or $N)$}

Severity 2

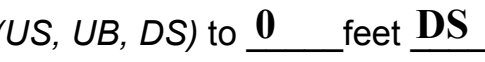

Exist? $\mathbf{N}(Y$ or $N)$

Severity - 
18. Bridge Type: 1a

1a- Vertical abutments with wingwalls

$1 \mathrm{~b}$ - Vertical abutments without wingwalls

2- Vertical abutments and wingwalls, sloping embankment Wingwalls parallel to abut. face

3- Spill through abutments

4- Sloping embankment, vertical wingwalls and abutments

Wingwall angle less than $90^{\circ}$.

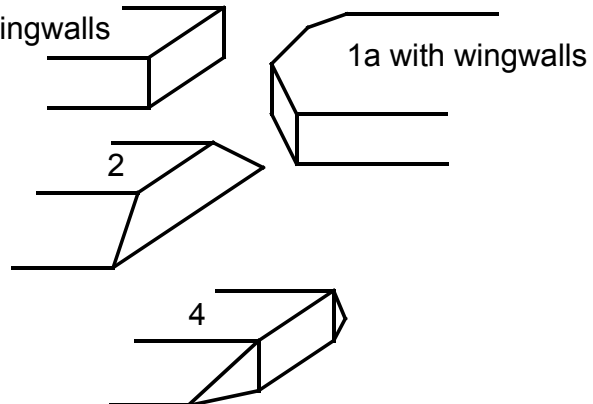

19. Bridge Deck Comments (surface cover variations, measured bridge and span lengths, bridge type variations, approach overflow width, etc.)

4. Chase Mountain Road runs along the US left bank and Cox Brook Road is on the US right bank.

7. Values are from the VT AOT files. Measured bridge span is $25 \mathrm{ft}$, bridge length is $29 \mathrm{ft}$, and the bridge width is $21.4 \mathrm{ft}$ measured perpendicular to the edge of the curb and $23 \mathrm{ft}$ measured at the abutment angle. 11. The US right wingwall acts as road approach protection.

13. The DS left bank road approach is eroded around the end of the DS left wingwall.

\section{Upstream Channel Assessment}

\begin{tabular}{|c|c|c|c|c|c|c|c|c|c|c|c|}
\hline & \multicolumn{4}{|c|}{ 21. Bank height (BF) 22. Bank anqle (BF) } & \multicolumn{2}{|c|}{ 26. \% Veg. cover (BF) } & \multicolumn{3}{|c|}{ 27. Bank material (BF) } & \multicolumn{2}{|c|}{ 28. Bank erosion (BF } \\
\hline 20. SRD & LB & RB & LB & RB & LB & RB & LB & RB & & LB & $\mathrm{RB}$ \\
\hline 33.5 & 4. & & & 6.0 & 3 & 1 & 32 & 23 & & 1 & 1 \\
\hline 23. Bank v & dth & & 24. & nel width & 40.0 & 25. Tha & Iweg depth & 23.5 & & 9. Bed Material & 43 \\
\hline 30 .Bank p & otecti & pe: & LB $\underline{2}$ & RB $\underline{\mathbf{0}}$ & & 31. Bank pr & otection cor & dition: & LB 1 & $\mathrm{RB}=$ & \\
\hline $\begin{array}{l}\text { SRD - Se } \\
\text { Bed and } \\
\text { Bank Ero } \\
\text { Bank pro } \\
\text { Bank pro }\end{array}$ & $\begin{array}{l}\text { on } r \\
\text { nk } N \\
\text { n: } 0 \\
\text { tion }\end{array}$ & $\begin{array}{l}\text { evid } \\
0\end{array}$ & $\begin{array}{l}\text { face } \\
\text { ganics } \\
\text { bble, } \\
1-\text { lig } \\
\text { ent; } 1\end{array}$ & $\begin{array}{l}\text { \% Veget } \\
\text { t / clay, } \\
56 \mathrm{~mm} ; \\
\text { ial; 2- }\end{array}$ & $\begin{array}{l}7(\mathrm{Veg} \\
16 \mathrm{~mm} \\
\text { ulder, } \\
\text { rate fl }\end{array}$ & $\begin{array}{l}\text { r: 1- } 0 \text { to } \\
n d, 1 / 16 \\
m m ; 6-b \\
- \text { heavy } \\
3-<48 \text { ir }\end{array}$ & $\begin{array}{l}\text { o; 2- } 26 \\
\text { nm; 3- } \\
\text { ock; 7- }\end{array}$ & $\begin{array}{l}0 \% ; 3- \\
\text { made } 2 \text { - } 6 \\
\text { asting }\end{array}$ & & $75 \% ; 4-76$ & $100 \%$ \\
\hline
\end{tabular}

32. Comments (bank material variation, minor inflows, protection extent, etc.):

30. The left bank protection extends from the end of the wingwall at $5 \mathrm{ft}$ US to $22 \mathrm{ft}$ US.

29. The bed material grades to some sand on the right side. 
33.Point/Side bar present? $\mathbf{Y}$

$(Y$ or $N$. if $N$ type ctrl-n pb) 34 . Mid-bar distance: $\mathbf{5 1}$

35. Mid-bar width: $\mathbf{5}$

36. Point bar extent: 32 feet US

(US, UB) to 62 feet $\underline{\mathbf{U S}}$

(US, UB, DS) positioned $\mathbf{0}$ $\%$ LB to 35 $\%$ RB

37. Material: $\mathbf{3}$

38. Point or side bar comments (Circle Point or Side; Note additional bars, material variation, status, etc.):

This side bar is vegetated with grass. Another point bar is from $21 \mathrm{ft}$ US to $4 \mathrm{ft}$ DS and positioned from $40 \%$ LB to $100 \%$ RB. The mid-bar is $10 \mathrm{ft}$ wide and is located at the US face of the bridge. This point bar is gravel and vegetated with grass on the US end.

39. Is a cut-bank present? $\mathbf{N}$ ( $Y$ or if $N$ type ctrl-n $c b)$

40. Where? ( $L B$ or $R B)$

41. Mid-bank distance: -

42. Cut bank extent: feet (US, UB) to feet (US, UB, DS)

43. Bank damage: = (1- eroded and/or creep; 2- slip failure; 3- block failure)

44. Cut bank comments (eg. additional cut banks, protection condition, etc.):

There are no cut-banks.

45. Is channel scour present? $\mathbf{N}$ ( $Y$ or if $N$ type ctrl-n cs)

47. Scour dimensions: Length Width Depth :46. Mid-scour distance: -

48. Scour comments (eg. additional scour areas, local scouring process, etc.):

There is no channel scour present.

49. Are there major confluences? $\mathbf{N}$

51. Confluence 1: Distance Confluence 2: Distance 52. Enters on Enters on 54. Confluence comments (eg. confluence name):

There are no major confluences upstream at this site.
50. How many? -

53. Type(1- perennial; 2- ephemeral) Type (1- perennial; 2- ephemeral) (LB or $R B)$

\section{Under Bridge Channel Assessment}

55. Channel restraint (BF)? LB 2

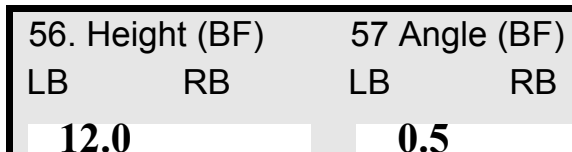

58. Bank width (BF) (1- natural bank; 2- abutment; 3- artificial levee)

Bed and bank Material: 0- organics; 1- silt / clay, < 1/16mm; 2- sand, 1/16 - 2mm; 3- gravel, 2 - 64mm; 4- cobble, 64 - 256mm; 5- boulder, > 256mm; 6- bedrock; 7- manmade

Bank Erosion: 0- not evident; 1- light fluvial; 2- moderate fluvial; 3- heavy fluvial / mass wasting

64. Comments (bank material variation, minor inflows, protection extent, etc.):

34 
65. Debris and Ice Is there debris accumulation?

$(Y$ or $N)$ 66. Where? $\mathbf{N}$

(1- Upstream; 2- At bridge; 3- Both)

67. Debris Potential ( 1- Low; 2- Moderate; 3- High)

68. Capture Efficiency 2 (1-Low; 2- Moderate; 3- High)

69. Is there evidence of ice build-up? 3 (Y or $N)$

Ice Blockage Potential $\underline{\mathbf{Y}}$

(1- Low; 2- Moderate; 3- High)

70. Debris and Ice Comments:

3

The pointbar on the right abutment and the low vertical clearance of the bridge contribute to the capture efficiency rating for debris and ice potential. There is also some debris accumulation DS.

\begin{tabular}{|l|c|c|c|c|c|c|c|c|}
\hline Abutments & $\begin{array}{c}\text { 71. Attack } \\
\angle \text { (BF) }\end{array}$ & $\begin{array}{c}72 \text {. Slope } \angle \\
\text { (Qmax) }\end{array}$ & $\begin{array}{c}\text { 73. Toe } \\
\text { loc. (BF) }\end{array}$ & $\begin{array}{c}\text { 74. Scour } \\
\text { Condition }\end{array}$ & $\begin{array}{c}75 . \text { Scour } \\
\text { depth }\end{array}$ & $\begin{array}{c}\text { 76. Exposure } \\
\text { depth }\end{array}$ & 77. Material & 78. Length \\
\hline LABUT & & $\mathbf{3 0}$ & $\mathbf{9 0}$ & $\mathbf{0}$ & $\mathbf{2}$ & $\mathbf{1}$ & $\mathbf{1}$ & $\mathbf{9 0 . 0}$ \\
\hline RABUT & $\mathbf{1}$ & $\mathbf{0}$ & $\mathbf{9 0}$ & & & $\mathbf{0}$ & $\mathbf{0}$ & $\mathbf{1 9 . 0}$ \\
\hline
\end{tabular}

Pushed: $L B$ or RB

Toe Location (Loc.): 0- even, 1- set back, 2- protrudes

Scour cond.: 0- not evident; 1- evident (comment); 2- footing exposed; 3-undermined footing; 4- piling exposed; 5- settled; 6- failed

Materials: 1- Concrete; 2- Stone masonry or drywall; 3- steel or metal; 4- wood

79. Abutment comments (eg. undermined penetration, unusual scour processes, debris, etc.):

$-$

1

75. Average thalweg depth is $0.5 \mathrm{ft}$ There is some concrete spalling of the left abutment at the corner between the bottom of the abutment and the top of the footing. In places the streamward edge of the left abutment footing is eroded away 2 in. to 3 in., but it is not undermined.

80. Wingwalls:

$\begin{array}{llll} & & & \\ \text { Exist? Material? } & \text { Scour } & \text { Scour } & \text { Exposure } \\ \text { Condition? } & \text { depth? } & \text { depth? }\end{array}$

USLWW:

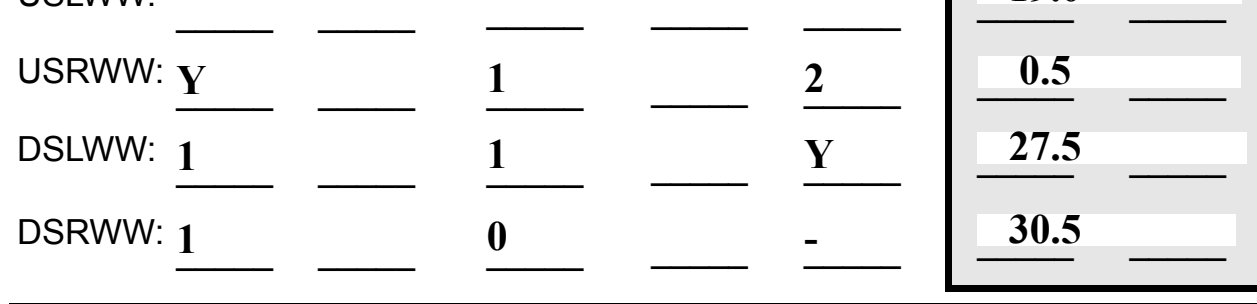

Wingwall materials: 1- Concrete; 2- Stone masonry or drywall; 3- steel or metal; 4- wood

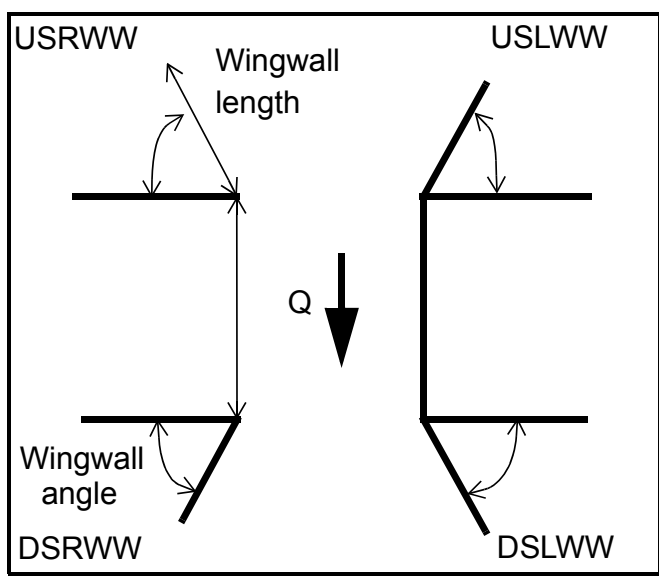

82. Bank / Bridge Protection:

\begin{tabular}{|l|l|l|l|l|l|l|c|c|}
\hline Location & USLWW & USRWW & LABUT & RABUT & LB & RB & DSLWW & DSRWW \\
\hline Type & - & $\mathbf{2}$ & $\mathbf{Y}$ & - & - & - & - & - \\
\hline Condition & $\mathbf{Y}$ & $\mathbf{0}$ & $\mathbf{1}$ & - & - & - & - & - \\
\hline Extent & $\mathbf{1}$ & $\mathbf{0 . 5}$ & $\mathbf{0}$ & $\mathbf{0}$ & $\mathbf{0}$ & $\mathbf{0}$ & $\mathbf{0}$ & - \\
\hline
\end{tabular}

Bank / Bridge protection types: 0- absent; 1- < 12 inches; 2- < 36 inches; 3- < 48 inches; 4- < 60 inches; 
83. Wingwall and protection comments (eg. undermined penetration, unusual scour processes, etc.):

-
-
-
-
-
0
-
-
0
-
-

\section{Piers:}

84. Are there piers? 80. (Y or if $N$ type ctrl-n pr)

\begin{tabular}{|l|l|l|l|l|l|l|l|}
\hline \multirow{2}{*}{$\begin{array}{l}85 . \\
\text { Pier no. }\end{array}$} & \multicolumn{3}{|c|}{ width (w) feet } & \multicolumn{3}{c|}{ elevation (e) feet } \\
\cline { 2 - 8 } & w1 & w2 & w3 & e@w1 & e@w2 & e@w3 \\
\hline Pier 1 & & $\mathbf{1 4 . 5}$ & & $\mathbf{1 3 5 . 0}$ & $\mathbf{0 . 0}$ & $\mathbf{1 0 . 0}$ \\
\hline Pier 2 & & $\mathbf{7 . 0}$ & $\mathbf{7 . 5}$ & $\mathbf{5 5 . 0}$ & $\mathbf{1 3 0 . 0}$ & - \\
\hline Pier 3 & - & - & - & - & - & - \\
\hline Pier 4 & - & - & - & - & - & - \\
-
\end{tabular}

\begin{tabular}{|l|l|l|l|l|}
\hline Level 1 Pier Descr. & \multicolumn{1}{|c|}{1} & \multicolumn{1}{|c|}{2} & \multicolumn{1}{|c|}{3} & \multicolumn{1}{|c|}{} \\
\hline 86. Location (BF) & The & the & up to 6 & - \\
\hline 87. Type & US & wing & in. & - \\
\hline 88. Material & left & wall & & - \\
\hline 89. Shape & wing & and & & - \\
\hline 90. Inclined? & wall & the & & - \\
\hline 91. Attack $\angle$ (BF) & area & top & & - \\
\hline 92. Pushed & betw & of & & - \\
\hline 93. Length (feet) & - & - & - & - \\
\hline 94. \# of piles & een & the & & - \\
\hline 95. Cross-members & the & foot- & & - \\
\hline 96. Scour Condition & bot- & ing is & & - \\
\hline 97. Scour depth & tom & erod & & - \\
\hline 98. Exposure depth & of & ed & N & - \\
\hline
\end{tabular}

LFP, LTB, LB, MCL, MCM, MCR, RB, RTB, RFP

1- Solid pier, 2- column, 3- bent

1-Wood; 2- concrete; 3- metal; 4- stone

1- Round; 2- Square; 3- Pointed

Y-yes; $N$ - no

$L B$ or $R B$

0- none; 1- laterals; 2- diagonals; 3- both

0- not evident; 1- evident (comment);

2- footing exposed; 3- piling exposed;

4- undermined footing; 5- settled; 6 - failed 
99. Pier comments (eg. undermined penetration, protection and protection extent, unusual scour processes, etc.):

-
-
-
-
-
-
-
-
-
-

100.

\section{E. Downstream Channel Assessment}

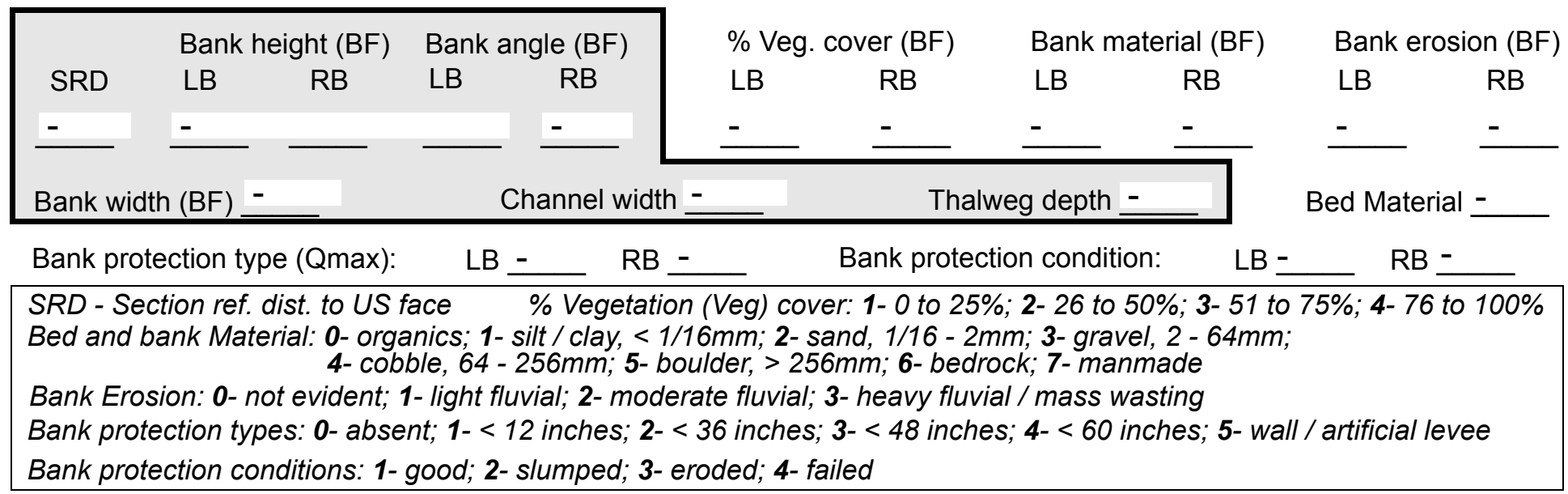

Comments (eg. bank material variation, minor inflows, protection extent, etc.):

-
-
-
-
-
-
-
-
-
-
-
-
-
-
-

101. Is a drop structure present? $\mathbf{T}$ ( $Y$ or $N$, if $N$ type ctrl-n ds) 102. Distance: __ feet

103. Drop: -_ feet 104. Structure material: her (1- steel sheet pile; 2- wood pile; 3- concrete; 4- other) 105. Drop structure comments (eg. downstream scour depth):

e are no piers. 


\section{Point bar extent:} feet $\underline{4}$

(US, UB, DS) to 4 feet $\mathbf{3 2}$ (US, UB,

UB, DS) S) positioned $\mathbf{3 2}$ $\%$ LB to 1

Material: 1

Point or side bar comments (Circle Point or Side; note additional bars, material variation, status, etc.):

\section{4}

0

$\mathbf{0}$

$-$

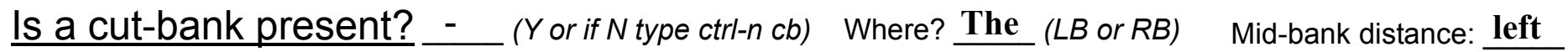
Cut bank extent: and feet rig (US, UB, DS) to ht feet ba (US, UB, DS)

Bank damage: $\mathbf{n k}$ (1-eroded and/or creep; 2- slip failure; 3- block failure)

Cut bank comments (eg. additional cut banks, protection condition, etc.):

vegetation cover is between $0 \%$ to $25 \%$ from the bridge face to $24 \mathrm{ft}$ DS.

Is channel scour present? ( $Y$ or if $N$ type ctrl-n cs)

Mid-scour distance:

Scour dimensions: Length Width Depth:

Positioned $\%$ LB to $\% \mathrm{RB}$

Scour comments (eg. additional scour areas, local scouring process, etc.):

Are there major confluences? $\mathbf{N}$ ( $Y$ or if $N$ type ctrl-n $m c)$ Confluence 1: Distance Ther Confluence 2: Distance drop Enters on $\underline{\mathbf{e} \text { is }}$ ( $L B$ or $R B)$ Enters on stru (LB or RB) Confluence comments (eg. confluence name):

e at this site.
How many? -

Type no (1- perennial; 2- ephemeral)

Type ctur (1- perennial; 2- ephemeral)

\section{F. Geomorphic Channel Assessment}

107. Stage of reach evolution
1- Constructed

2- Stable

3- Aggraded

4- Degraded

5- Laterally unstable

6- Vertically and laterally unstable 
108. Evolution comments (Channel evolution not considering bridge effects; See HEC-20, Figure 1 for geomorphic descriptors):

$\mathbf{N}$

$-$

$-$

$-$

$-$

$-$

$-$

-

$-$ 


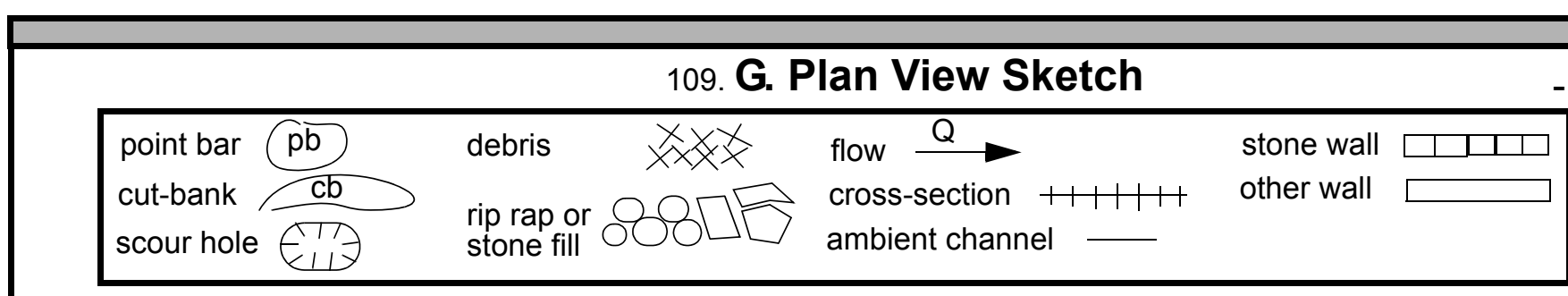

cut-bank $\mathrm{cb}$

scour hole rip rap or
stone fill stone fill cross-section $+1+1+1$ ambient channe other wall 
APPENDIX F:

SCOUR COMPUTATIONS 
SCOUR COMPUTATIONS

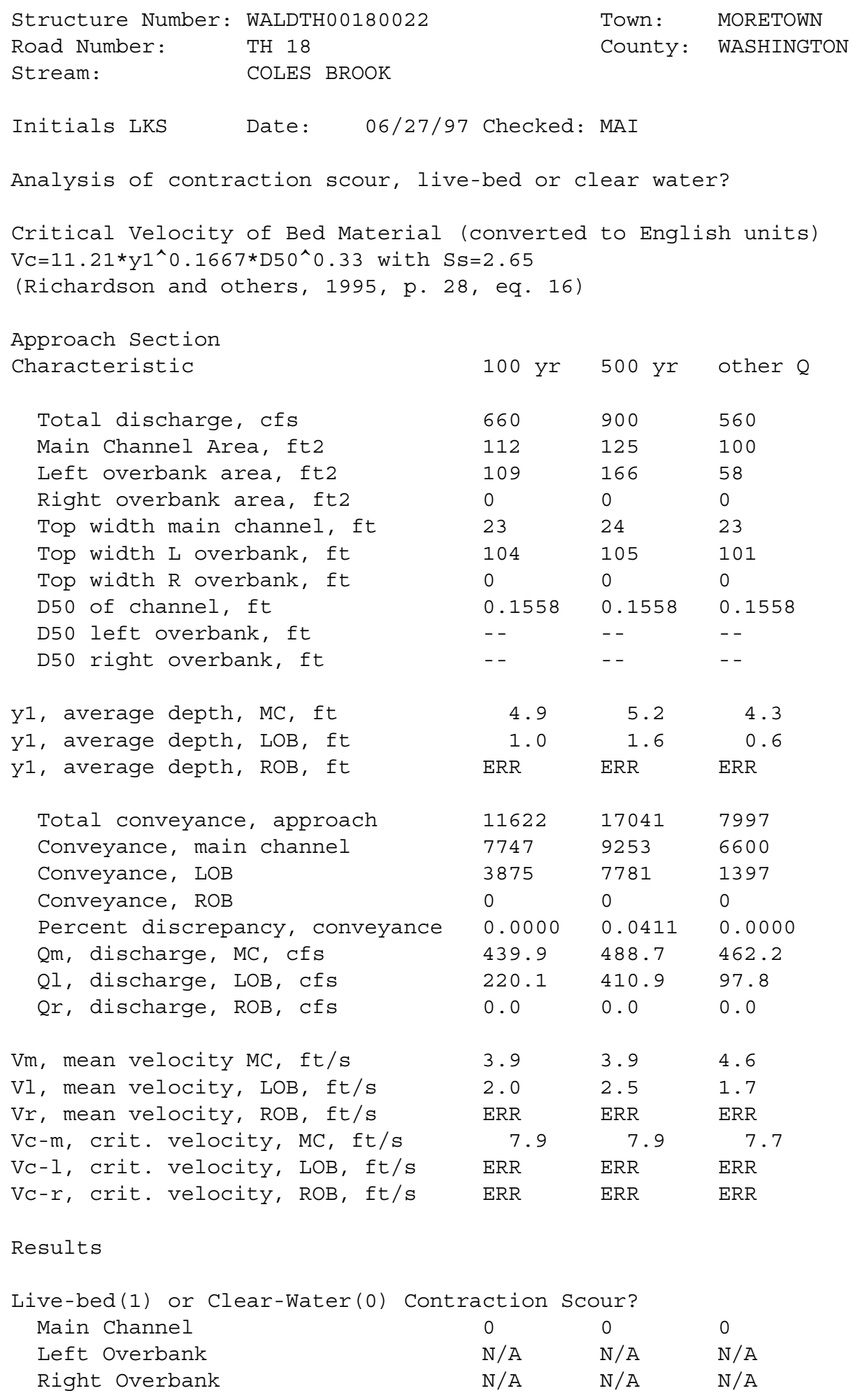


Clear water Contraction Scour in MAIN CHANNEL

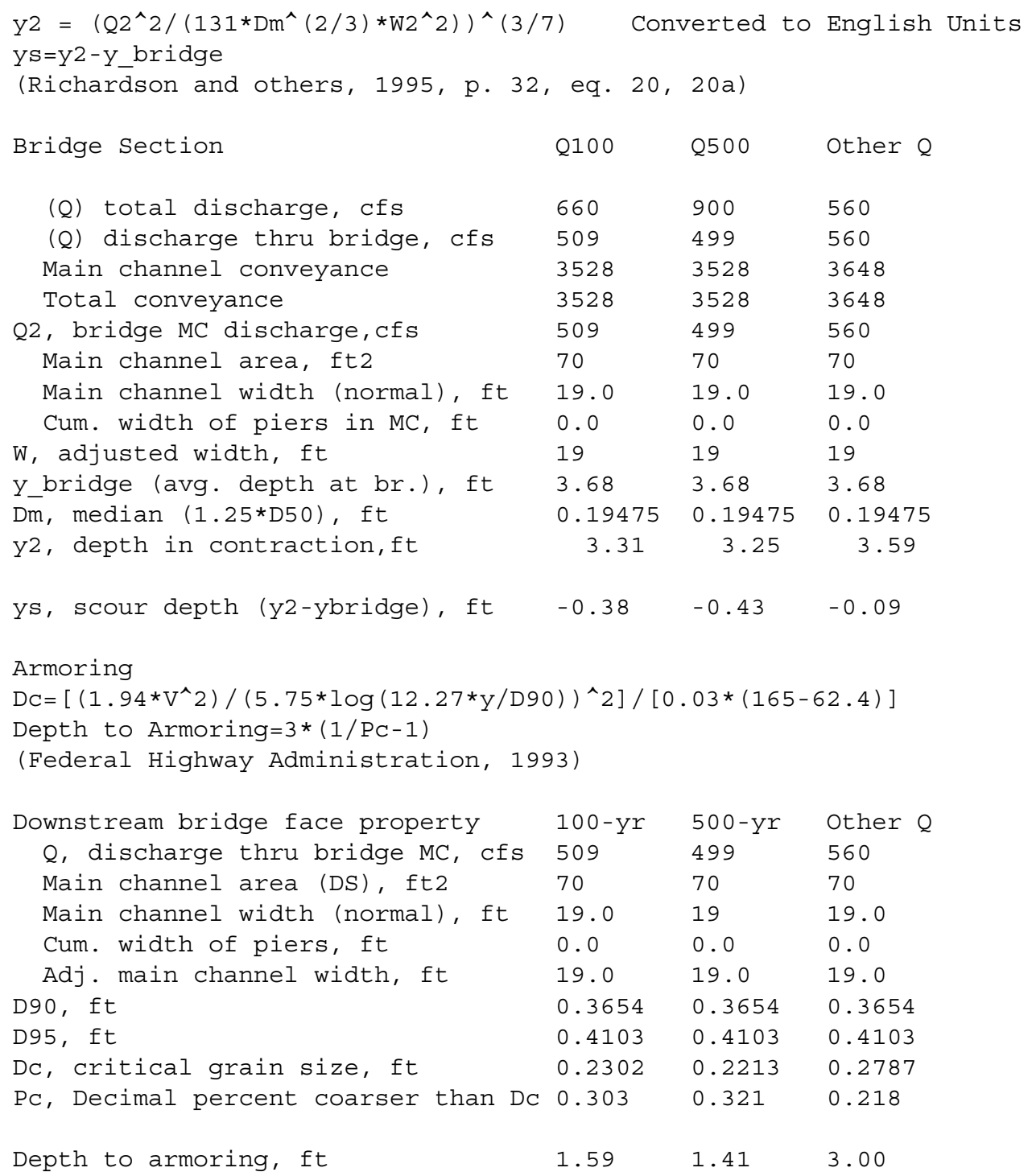




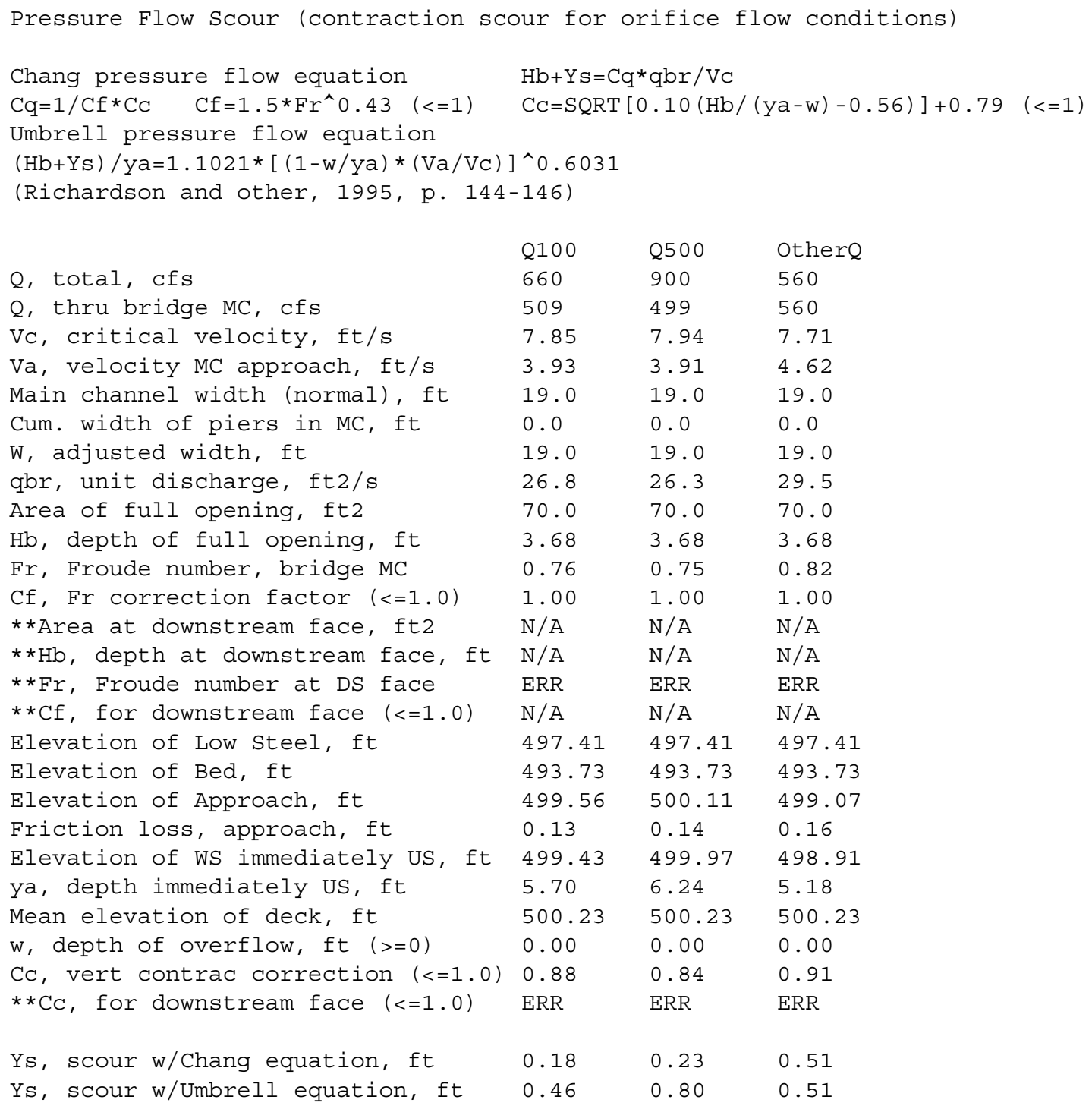




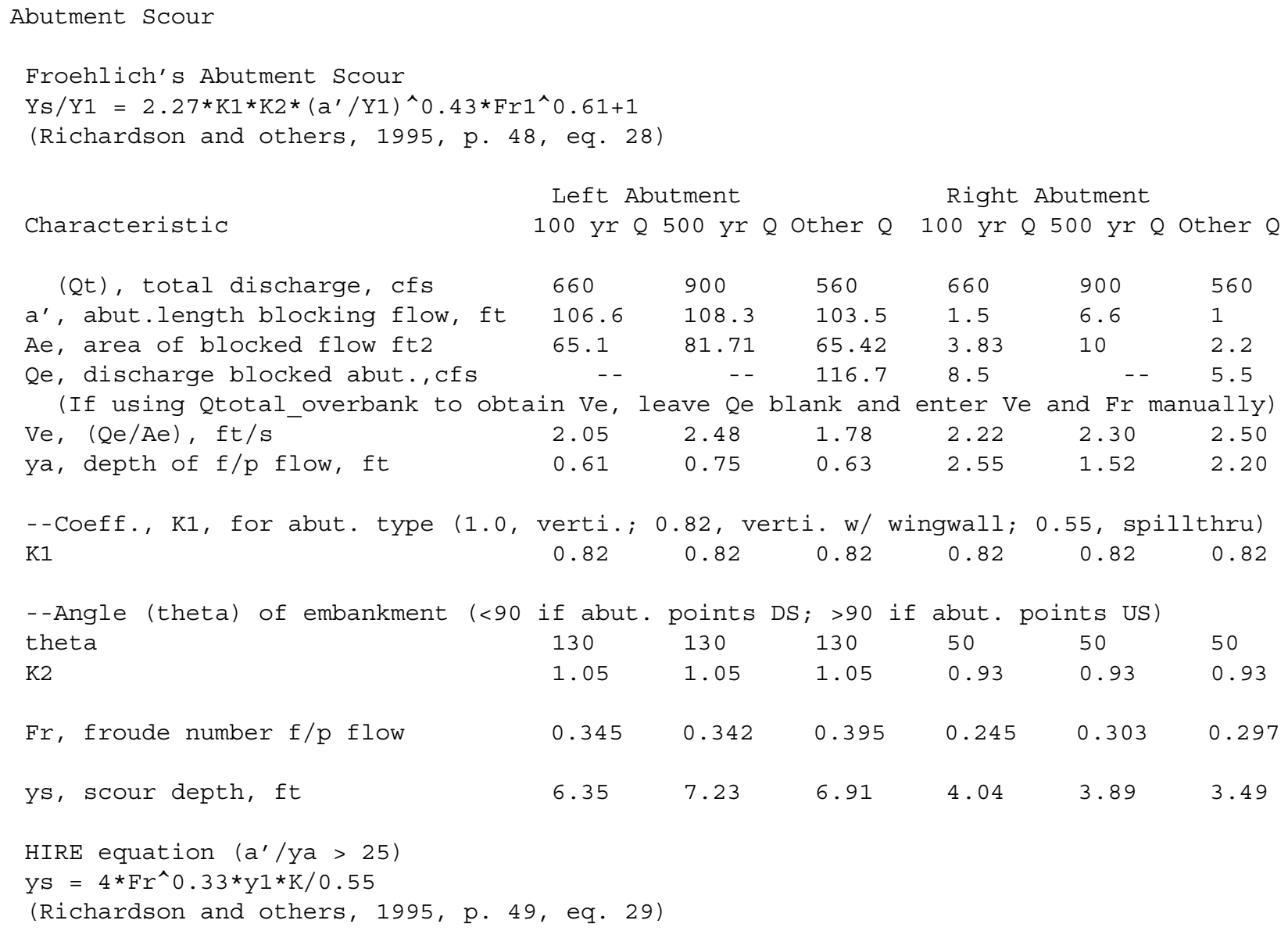




\begin{tabular}{|c|c|c|c|c|c|c|}
\hline a' (abut length blocked, ft) & 106.6 & 108.3 & 103.5 & 1.5 & 6.6 & 1 \\
\hline y1 (depth f/p flow, ft) & 0.61 & 0.75 & 0.63 & 2.55 & 1.52 & 2.20 \\
\hline$a^{\prime} / y 1$ & 174.56 & 143.54 & 163.75 & 0.59 & 4.36 & 0.45 \\
\hline Skew correction (p. 49, fig. 16) & 1.09 & 1.09 & 1.09 & 1.00 & 1.00 & 1.00 \\
\hline Froude no. f/p flow & 0.35 & 0.34 & 0.40 & 0.24 & 0.30 & 0.30 \\
\hline Ys w/ corr. factor $\mathrm{K} 1 / 0.55$ : & 3.40 & 4.19 & 3.69 & $\mathrm{FRR}$ & $\mathrm{FRR}$ & FRR \\
\hline vertical w/ ww's & 2.79 & $\begin{array}{l}4.19 \\
3.44\end{array}$ & $\begin{array}{l}3.09 \\
3.02\end{array}$ & $\begin{array}{l}\text { ERR } \\
\text { ERR }\end{array}$ & $\begin{array}{l}\text { ERR } \\
\text { ERR }\end{array}$ & $\mathrm{ERR}$ \\
\hline spill-through & 1.87 & 2.31 & 2.03 & ERR & ERR & ERR \\
\hline \multicolumn{7}{|l|}{ Abutment riprap Sizing } \\
\hline \multirow{2}{*}{\multicolumn{7}{|c|}{$\begin{array}{l}\text { Isbash Relationship } \\
\mathrm{D} 50=\mathrm{Y}^{\star} \mathrm{K} * \mathrm{Fr} r^{\wedge} 2 /(\mathrm{Ss}-1) \text { and } \mathrm{D} 50=\mathrm{Y} * \mathrm{~K} *\left(\mathrm{Fr} r^{\wedge} 2\right)^{\wedge} 0.14 /(\mathrm{Ss}-1) \\
\text { (Richardson and others, 1995, p112, eq. 81,82) }\end{array}$}} \\
\hline & & & & & & \\
\hline Characteristic & Q100 & Q500 & Other $\mathrm{Q}$ & Q100 & Q500 & Other $Q$ \\
\hline Fr, Froude Number & 0.76 & 0.75 & 0.82 & 0.76 & 0.75 & 0.82 \\
\hline$y$, depth of flow in bridge, ft & 3.68 & 3.68 & 3.68 & 3.68 & 3.68 & 3.68 \\
\hline \multicolumn{7}{|c|}{ Median stone Diameter for riprap at: left abutment } \\
\hline Fr<=0.8 (vertical abut.) & 1.31 & 1.28 & ERR & 1.31 & 1.28 & ERR \\
\hline Fr>0.8 (vertical abut.) & ERR & ERR & 1.46 & ERR & ERR & 1.46 \\
\hline Fr $<=0.8$ (spillthrough abut.) & 1.15 & 1.12 & ERR & 1.15 & 1.12 & ERR \\
\hline Fr>0.8 (spillthrough abut.) & $\mathrm{ERR}$ & ERR & 1.29 & ERR & ERR & 1.29 \\
\hline
\end{tabular}

